Tom VI, Numer 2 - Lipiec 2010

https://doi.org/10.18778/1733-8069.6.2.01

Krzysztof Konecki

Uniwersytet Lódzki, Polska

\title{
Wizualna Teoria Ugruntowana. Nauczanie teorii ugruntowanej przy pomocy obrazów i analizy wizualnej²
}

\begin{abstract}
Abstrakt
Artykuł powstał na podstawie mojego 20-letniego doświadczenia w nauczaniu metod jakościowych i teorii ugruntowanej. Chciałbym w nim pokazać użyteczność analizy wizualnej w nauczeniu metodologii teorii ugruntowanej i konstruowaniu kategorii i hipotez przy pomocy obrazów. Proces nauczania będzie pokazany na przykładzie realizowanego projektu badawczego dotyczącego bezdomności.

Bardzo ważnym narzędziem jest sekwencjonowanie obrazów/zdjęć, które daje porównawczy wgląd w dane empiryczne i uczy metody porównawczej. Studenci mogą się nauczyć porównywać i odnajdywać wzory w empirycznych przykładach mających charakter wizualny. Niektóre z sekwencji pokazują fazy działań. W innych przypadkach kolejność zdjęć danych studentom nie jest dokładnie zaplanowana. Kolejność jest niemal przypadkowo (i sztucznie) stworzona, co zmusza studentów do znalezienia wzorów przy pomocy analizy porównawczej. Powinniśmy zawsze mieć świadomość tego co widzieliśmy przed obejrzeniem danej fotografii i co ewentualnie będziemy widzieć dalej - wszystko to ma wpływ na to co widzimy aktualnie. Przypomina to trochę analizę sekwencyjną danych tekstowych (Silverman 2007: 61-84, 146).

W tego typu analizie zachęca się również studentów do nasycania kategorii przy pomocy danych pochodzących z obrazów. Dzięki temu nie tracą oni świadomości powiązań podczas przechodzenia od empirycznych przykładów do opracowanych koncepcyjnie własności kategorii i w końcu do ich definicji oraz tez teoretycznych. W ten sposób studenci uczą się również nasycania kategorii i ostatecznie uczą się jak budować teorię ugruntowaną przy pomocy obrazów, to jest uczą się generowania kategorii, własności i tez poprzez kodowanie i analizę teoretyczną obrazów.
\end{abstract}

Dane adresowe autora: Katedra Socjologii Organizacji i Zarządzania,Instytut Socjologii, Wydział Ekonomiczno-Socjologicz ny UŁ, ul. Rewolucji 1905r. nr 41/43 90-214 Łódź,

E-mail:konecki@uni.lodz.pl

${ }^{2}$ Artykuł został przygotowany na podstawie referatu „Teaching Grounded Theory with Images and Visual Analysis” wygłoszonego na konferencji „Teaching Qualitative Methods”, zorganizowanej przez Qualitative Methods Research Network of European Sociological Association i Katedrę Socjologii Organizacji i Zarządzania ISUŁ oraz Sekcję Socjologii Jakościowej i Symbolicznego Interakcjonizmu PTS, Łódź, 15 - 17.09.2008. 


\section{Słowa kluczowe}

wizualna teoria ugruntowana, nasycanie kategorii, socjologia wizualna, fotografie, procesy wizualne, bezdomność, socjologia jakościowa, nauczanie metod jakościowych

Metody i wiedza o nauczaniu badań jakościowych rozwijają się bardzo szybko. Można nauczać metod jakościowych opierając się na prezentowanych przykładach nauczania (Hurworth 2008). Używa się coraz częściej nowoczesnych technicznych narzędzi nauczania. Istnieją przykłady nauczania przez Internet. Zorganizowanie tak zwany „Research Park On Line” pozwala na stworzenie społeczności badaczy uczących się wzajemnie od siebie, wymieniających pomysły oraz uczestniczących w tym samym projekcie badawczym (Chenail 2004). Sformułowanie jasnych celów nauczania w takim otoczeniu pozwala także włączyć nauczanie metod jakościowych i analizy jakościowej, na przykład metodologii teorii ugruntowanej (Chenail, Spong, Chenail, Liscio, McLean, Cox, Shepherd i Mowzoon 2006).

You Tube, usługa magazynująca i dystrybuująca nagrania wideo także może być znakomitym narzędziem nauczania metod jakościowych, na przykład dzięki zamieszczaniu nagranych na wideo wykładów, prezentacji Power Point, nagrań pokazujących zbieranie danych i konteksty zbierania danych. Na You Tube możemy znaleźć nagrania wideo będące wprowadzeniem do metod badan jakościowych (Chenail 2008). Znajdujemy tam także klipy nauczające teorii ugruntowanej począwszy od przygotowania do kodowania danych, analizy i konstruowania teorii ugruntowanej (http://www.youtube.com/watch?v=em3dRhwQEAA) i inne na przykład wyjaśniające metodę ciągłego porównywania i triangulację (http://www.youtube.com/watch?v=FtyNe9w5Pb4). Niektóre pisma on line nauczają i pomagają nowym adeptom metodologii jakościowej w pisaniu artykułów. Pismo „The Qualitative Research" pomaga początkującym badaczom jakościowym pisać raporty badawcze $\mathrm{w}$ formie artykułów naukowych. Pomoc dotyczy otrzymania dostępu do źródeł (książki, artykuły), edytowania, nauczania formatu pisania artykułów oraz poprzez dawanie intensywnej informacji zwrotnej dla autorów (Chenail, St. George, Wulff, Duffy, Laughlin, Warner i Sahni 2007).

Ja zazwyczaj uczę metod jakościowych poprzez projekty badawcze. Studenci otrzymują ogólny zarys projektu badawczego i obszaru badań po czym zostają zaproszeni do uczestnictwa w projekcie. Gdy studenci zostaną już zapoznani z metodami i procedurami, zaczynają zbierać dane ucząc się korzystania z różnych technik. Dane są zbierane przy pomocy różnych technik by nauczyć się ich używania, oraz by nauczyć się znajdowania nowych „warstw danych” (w tym danych z internetu), które pomagają w generowaniu własności kategorii, szczególnie tych związanych z warunkami i konsekwencjami (Glaser, Strauss 1967: 65 - 69). Przez cały proces zbierania danych są one analizowane podczas zajęć, które w zasadzie są sesjami analitycznymi. Studenci wymieniają się danymi i notami badawczymi oraz teoretycznymi na temat kategorii by opracowywać dalej ich własności i konstruować hipotezy (zob. Corbin, Strauss 2007: 15, 20, 60, 156; Charmaz 2009, porównaj także Hesse - Biber, 2007).

W artykule stawiamy sobie trzy cele do realizacji. Pierwszym i najważniejszym jest opisanie sposobów nauczania teorii ugruntowanej przy pomocy wizualnych danych. Dwa pozostałe cele są podporządkowane pierwszemu:

- opisanie praktycznego użycia wizualnej teorii ugruntowanej, 
- pokazanie analizy danych wizualnych poprzez zaprezentowanie w skrócie rezultatów badań (i analiz danych empirycznych) nad bezdomnością przeprowadzonych razem ze studentami.

Taki dydaktyczny projekt dotyczący bezdomnych był realizowany $w$ Łodzi (Uniwersytet Łódzki, 2008, czerwiec - lipiec) z udziałem studentów kierunku praca socjalna. Jednym $z$ dydaktycznych celów projektu było nauczenie studentów wrażliwości $\mathrm{i}$ dogłębnego zaznajomienia się $z$ daną dziedziną badań. Projekt badawczy był związany z przyjętym wcześniej ogólnym zarysem zbierania informacji o „byciu bezdomnym”. Do badań użyto metodologii teorii ugruntowanej i takich technik badawczych jak wywiady narracyjne (20 wywiadów wykonanych i przepisanych w ciągu miesiąca), swobodne (40 wywiadów wykonanych i przepisanych w ciągu miesiąca), wykonywanie fotografii (800 fotografii wykonanych w ciągu miesiąca i opisanych) oraz powtarzające się wizyty w schroniskach. Dane były zbierane zarówno w schroniskach, jak i w miejscach gdzie żyją bezdomni (na ulicach, w lasach, parkach, pustostanach). Bezdomni byli proszeni o wskazanie fotografowi obiektów i otoczenia, które ukazują ich tożsamość, a także przeszłość, teraźniejszość i przyszłość, wymiary związane z ich życiem i tożsamością. Rozpoczęliśmy projekt zbieraniem fotografii bezdomnych ludzi, które następnie analizowaliśmy. Na początku zbieraliśmy dane (fotografie) w internecie. Do analizy użyliśmy także danych o charakterze nagrań wideo, artykułów prasowych, oraz informacji o bezdomnych i bezdomności.

Dając takie zadania studentom istnieje zatem możliwość nauczania nie tylko technicznych aspektów zbierania danych empirycznych, lecz także socjologicznej i teoretycznej wrażliwości i, co więcej, wrażliwości społecznej. Obie te wrażliwości są uzyskiwane przez wykonywanie i/lub analizowanie obrazów/fotografii podczas pracy grupowej. Mieścimy się tutaj w pewnej tradycji konstruktywistycznej w budowaniu teorii ugruntowanej odnoszącej się zapewne do inspiracji pragmatyzmu w socjologii (Charmaz 2009; Bryant, Charmaz 2007; Strubing 2007).

Obserwując sytuacje przedstawione na zdjęciach, możemy postawić się w sytuacji uczestnika wydarzeń lub osoby obserwującej. W obu tych przypadkach jesteśmy bardzo blisko badanej sytuacji, to jest zdecydowanie bliżej niż tylko czytając $\mathrm{i}$ analizując wypowiedzi werbalne. "Dogłębne zaznajomienie się $z$ obszarem rzeczowym" naszych badań (intimate familiarity) wg H. Blumera (1969/2007) jest także kwestią pamięci, dla której zdjęcia mogą stanowić dobrą "protezę". Fotografie mogą także czasami dać nam więcej informacji na temat warunków życia niż badani aktorzy społeczni przy pomocy wypowiedzi werbalnych (patrz dalej paragraf 5 „Nasycanie kategorii”). Wiedza o sytuacji jest związana ze zdolnością wyniesienia $z$ badanego obszaru jak największej ilości informacji i przeniesienia ich do plików w komputerze. Tutaj zdjęcia okazują się bardzo pomocne. Ponadto łączą one kontekst z kategoriami analitycznymi tak, że dokładnie widać, co jest konkretnie oznaczane przy pomocy danej kategorii i ciągle utrzymujemy związek naszego konceptualnego myślenia $z$ danymi empirycznymi, tutaj wizualnymi. To co robimy jest praktykowaniem wizualnej teorii ugruntowanej, co oznacza użycie wizualnych danych dla generowania kodów, kategorii i własności także dla nasycania kategorii i używania metody ciągłego porównywania. Wiele kategorii dotyczy procesów wizualnych, na przykład wizualizacji bezdomności, wizualnej estetyzacji bezdomności, wizualizacji firm, wizualizacji produktu, obrazowania relacji społecznych, i tym podobnych. Wszystkie rodzaje danych wizualnych mogą być użyte $w$ tego typu analizie. Dane wizualne są także pomocne $w$ konstruowaniu hipotez/tez teoretycznych. Możemy to czynić tak jak A. Clarke używając zarówno 
metodologii teorii ugruntowanej jak i analizy sytuacyjnej by badać dyskursy zarówno w wymiarze historycznym, narracyjnym czy czysto tekstowym oraz by generować mapy sytuacyjne tych dyskursów (2005: 146) lub, jak to my czynimy, koncentrować się na danych wizualnych jako ważnej "warstwie danych" w generowaniu teorii procesów wizualnych lub tylko „wizualnych własności” kategorii, które później utworzą teorię. Jednak powinniśmy pamiętać, że dane wizualne są pewnym sposobem widzenia rzeczywistości, który jest zawarty $w$ tego typu analizie i że "realizm wpatrywania się" (realism of gaze) powinien tutaj być dokładnie przeanalizowany: „Kto się wpatruje? Na kogo lub na co patrzy? Kto kontroluje wpatrywanie? Kto/co jest przedmiotem obserwacji? Jakie są tego konsekwencje?" (Clarke 2005: 210). Interpretacja obrazów nie jest odkrywaniem prawdy (Clarke: ibidem 257). Jeśli badacz wpatruje się $w$ kontekst swego badania i fotografuje lub nagrywa kamerą wideo działania badanych osób to kontekst "wpatrywania się" powinien również być poddany analizie.

\section{Etnograficzne badania wizualne bezdomnych - przykłady w nauczaniu}

Chcemy pokazać nasz sposób uprawiania wizualnej teorii ugruntowanej opierając się na badaniach nad bezdomnością. Istnieją wizualne badania bezdomnych korzystające z "podejścia kooperatywnego" gdzie badani biorą aktywny udział w tworzeniu danych do badania.

Radley, Hodgetts i Cullen badali bezdomnych przy pomocy metody fotograficznej. Chcieli odpowiedzieć na pytanie, w jaki sposób bezdomni są w stanie przetrwać w mieście i jak swoje wysiłki wizualizują? Poprosili dwunastu bezdomnych by wykonali fotografie pokazujące kluczowe momenty ich dnia, typowe zajęcia, miejsca lub cokolwiek innego odzwierciedlającego ich sytuację życiową (Radley, Hodgetts i Cullen 2005: 277). Wywiady zostały przeprowadzone przed i po wykonaniu zdjęć. Według autorów fotografie dodały wiele ważnych informacji - na temat przestrzeni i materialnych przedmiotów, informacje te nie zostałyby uzyskane dzięki wywiadom.

Inne badanie wizualne dotyczy „miejsc pobytu bezdomnych” i tego, jak są one widziane przez bezdomnych. Badanie dotyczy geografii bezdomności, miejsc znanych i ukrytych (Johnsen i In. 2008). Bezdomni byli proszeni o zrobienie zdjęć za pomocą aparatów dostarczonych przez badaczy. Badanie było rodzajem autofotografii, robionej po pogłębionych wywiadach („osobista historia”, „moja droga do bezdomności"). Po wykonaniu zdjęć bezdomni byli pytani o ich treść i znaczenia. Fotografie dały kartograficzny obraz miejsc zamieszkałych przez bezdomnych. Pokazywały one dobrze znane miejsca, takie jak parkingi, schroniska, uliczne strefy picia, squaty i mniej znane, jak kempingi i miejsca do żebrania. Niektóre miejsca nie zostały sfotografowane ze względu na niemożliwy dostęp do określonych obszarów miasta (Johnsen i In. ibidem: 203).

W klasycznej pracy nad bezdomnymi napisanej przez Nels'a Anderson'a (1923/65) spotykamy się z prezentacją fotografii, które jednak nie zostały przeanalizowane. Fotografie są ilustracją treści i zostały użyte do wzbogacenia opisu życia bezdomnych (hobos). Fotografie te pokazują miejsca pobytu bezdomnych, miejsca skupień większych grup bezdomnych (jungle) czy miejsca letniego odpoczynku (Anderson ibidem: 12) a także miejsca spożywania posiłków na ulicy "Main Stem" w Chicago (Anderson ibidem: 34). Fotografie pokazują także działania bezdomnych, na przykład związane z edukacją bezdomnych (Anderson ibidem: 34 - 
35), lub „ulicznymi przemówieniami” dotyczącymi sytuacji ekonomicznej bezdomnych czy też są związane z religijnym nauczaniem (Anderson ibidem: 216 - 217).

Fotografie, w powyższym badaniu, zostały użyte jako dane dodatkowe pozwalające lepiej przedstawić czytelnikowi sytuację bezdomności. W naszym przypadku staramy się użyć dane wizualne dla celów analitycznych by przy pomocy metody porównawczej (Glaser 1965; Charmaz 2009; Corbin, Strauss 2007: 54) generować kategorie i własności kategorii. W naszym przypadku chodzi o porównywanie sfotografowanych obiektów i konceptualizację różnic pomiędzy nimi by generować pewne tezy teoretyczne.

\section{Porównywanie zdjęć w sekwencjach — sztuczna kolejność}

Zdjęcia dostarczają rzeczowej wiedzy na temat badanego obszaru, co jest bardzo ważne przy badaniach etnograficznych. Jednakże porównywanie zdjęć daje możliwość wygenerowania kategorii i ich własności. Jeśli porównamy zdjęcia bezdomnych między nimi będziemy mogli wygenerować własności dotyczące warunków ich życia (porównania homologiczne) ${ }^{3}$. Przy porównaniu fotografii z dwóch różnych obszarów rzeczowych z kolei, na przykład bezdomnego z przedsiębiorcą czy managerem wygenerujemy własności kategorii opisujące uwarstwienie społeczne lub „proces tworzenia uwarstwienia społecznego” (porównanie analogiczne) ${ }^{4}$. Natychmiast możemy wychwycić różnice, które stają się źródłem dystynkcji i własności kategorii. Poniżej znajduje się analiza fotografii pochodzących z badania z teoretycznymi notami, które pisaliśmy po analizie i porównywaniu fotografii.

Podczas oglądania zdjęć generowany jest natychmiast proces porównywania. Bez porównania niemożliwe jest rozumienie czy też stworzenie planu działania. Umysł pracuje porównując i wymaga sekwencji by stworzyć plan działania, który istnieje tylko w czasie, czyli jest trwającym procesem. Proces jest zwykle wyłaniającym się zestawem zachowań, które mogą być ze sobą porównywane.

Możemy mieć naturalną sekwencję pochodzącą z naturalnie sfotografowanej czynności w toku. Bierzemy zdjęcie jedno po drugim by pokazać, jak ludzie się zachowują, pracują, uczą, coś wytwarzają, i tym podobne. Odtwarzamy na zdjęciach to, co się "naprawdę" dzieje podczas obserwowanej sytuacji. Możemy także korzystać z kadrów nagrań wideo będących reprezentacją jakiegoś działania, na przykład: debatowania, bawienia się, spacerowania, walczenia (Liberman 2004; Goode 2007; Konecki 2008, sekwencje kadr z nagrań wideo pokazujące działania, zob. także poniżej sekwencję czterech fotografii pokazujących tybetańską filozoficzną debatę, Liberman 2004, www.thdl.org/DebateTutorials).

\section{A/ Sekwencja czterech fotografii $z$ nagrań wideo pokazujących debatę filozoficzną tybetańskich mnichów buddyjskich (Liberman 2004, www.thdl.org/DebateTutorials).}

\footnotetext{
${ }^{3}$ Homologiczne porównania służą wyjaśnianiu badanego zjawiska i ich celem jest pokazanie faz przejściowych danego zjawiska na podstawie porównań „obiektów” z tego samego obszaru rzeczowego (Konecki 2000: 60 - 76).

${ }^{4}$ Analogiczne porównania związane są z poszukiwanie wzoru interpretacji na podstawie podobieństw formalnie zróżnicowanych obiektów, najczęściej z różnych obszarów rzeczowych (Konecki ibidem).
} 

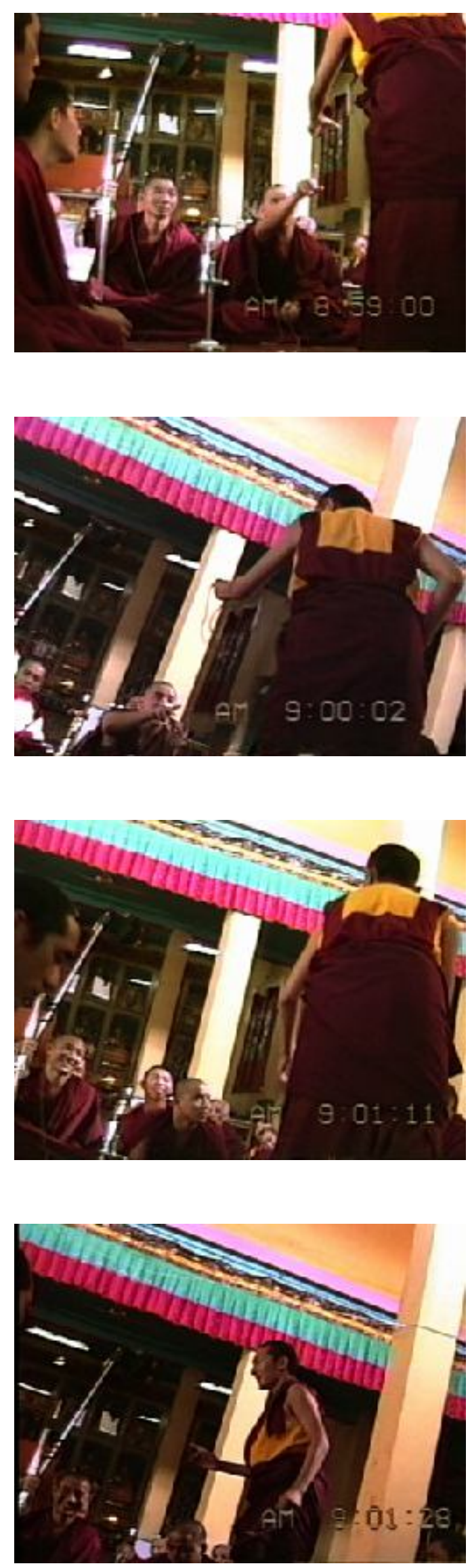
Możemy także stworzyć sztuczną sekwencję dla porównywania rzeczy lub czynności. Spójrzmy na sekwencję zdjęć głównie wykonanych przez bezdomnych z Klubu Fotograficznego działającego przy schronisku w Łodzi (zdjęcia wykonane przez bezdomnych zostały zaczerpnięte $z$ internetu, co jest oznaczone pod fotografiami, patrz dalej) i innych. Analizowaliśmy je razem ze studentami kierunku praca socjalna podczas praktyk (czerwiec, 2008; Łódź). W ten sposób mogliśmy otrzymać wizualną perspektywę świata z punktu widzenia bezdomnych. Chociaż ten dostęp do fotografii wydaje się odzwierciedlać podejście bezdomnych, powinniśmy pamiętać, że pewne konwencje fotograficzne i techniczne aspekty wykonywania zdjęć tworzą dane wizualne i są obecne w każdym akcie fotografowania (Banks 2007). Bezdomni również mają wizję tego, czym jest fotografia i fotografowanie.

Wybraliśmy kilkanaście zdjęć, które nie były intencjonalnie wyselekcjonowane by reprezentować niektóre aspekty życia bezdomnych. Fotografie te również nie prezentują żadnej czynności krok po kroku. Zostały one wybrane niemalże przypadkowo przez $\measuredangle$. Marciniaka, by pokazać coś interesującego dla studentów pracy socjalnej. Powinniśmy jednak pamiętać, że fotografie zostały wykonane przez bezdomnych. Studenci analizujący zdjęcia studiowali pracę socjalną i zostali następnie wysłani do schronisk dla bezdomnych a także na ulice, by zrobić z bezdomnymi wywiady narracyjne i swobodne, a także by wykonać zdjęcia przedmiotów i miejsc pokazujących ich tożsamość i nastawienie do przeszłości, teraźniejszości i przyszłości ${ }^{5}$. Staraliśmy się przygotować studentów do pracy badawczej i uwrażliwić na tematykę bezdomności przez pokazanie im zdjęć i analizowanie ich w grupie.

Zazwyczaj zaczynamy analizę od jednego zdjęcia, które jest szczegółowo opisane (zob. także Suchar 1997 oraz jego użycie fotografii w badaniach z użyciem metodologii teorii ugruntowanej). Na pierwszej fotografii znajdujemy pewne dystynkcje między przedmiotami, ludźmi, przestrzenią. To, co głównie w pierwszej chwili widzimy to bezdomny grabiący śmieci $z$ trawnika ${ }^{6}$.

\footnotetext{
${ }^{5}$ Podobnie badano autodefinicje mężczyzn i kobiet (Borkowska, Skrobacki 2008). Proszono respondentów o wykonanie zdjęć w swoim codziennym naturalnym środowisku by zaprezentować swe tożsamości. Dyspozycje dotyczyły między innymi: wskazania miejsc, z których respondenci są dumni; wskazania miejsc, które zaprezentowaliby innym by pokazać „kim jestem”; przedmiot, którego posiadanie mnie wyróżnia, itp. Inne badanie nad autodefinicjami przy użyciu fotografii polegało na dostarczeniu przez respondentów foto-pamiątek, które pokazywały ich tożsamość (Drozdowski 2008). Respondenci mieli tutaj dostarczyć fotografii, które miały odpowiedzieć na pytania: Kim jestem teraz?, Kim byłem, byłam kiedyś, ale już nie jestem?, oraz w jaki sposób chciałbym/chciałabym, aby widzieli mnie inni?

${ }^{6}$ Kolejność analizy prezentowana poniżej różni się od pierwszej prezentacji zdjęć przedstawionych studentom, kiedy zaczęliśmy je analizować. Ostatnia stworzona kolejność została zmieniona zgodnie z postępem analizy. Zaczęliśmy od pierwszego zdjęcia i procesu kontrastowania, jednakże nie dlatego, że zdjęcia były ułożone w sposób sugerujący powstanie tej kategorii. Stworzenie sekwencji zdjęć podczas analizy i prezentacji jest efektem analizy i wyboru tematu przez analizującego fotografie.
} 


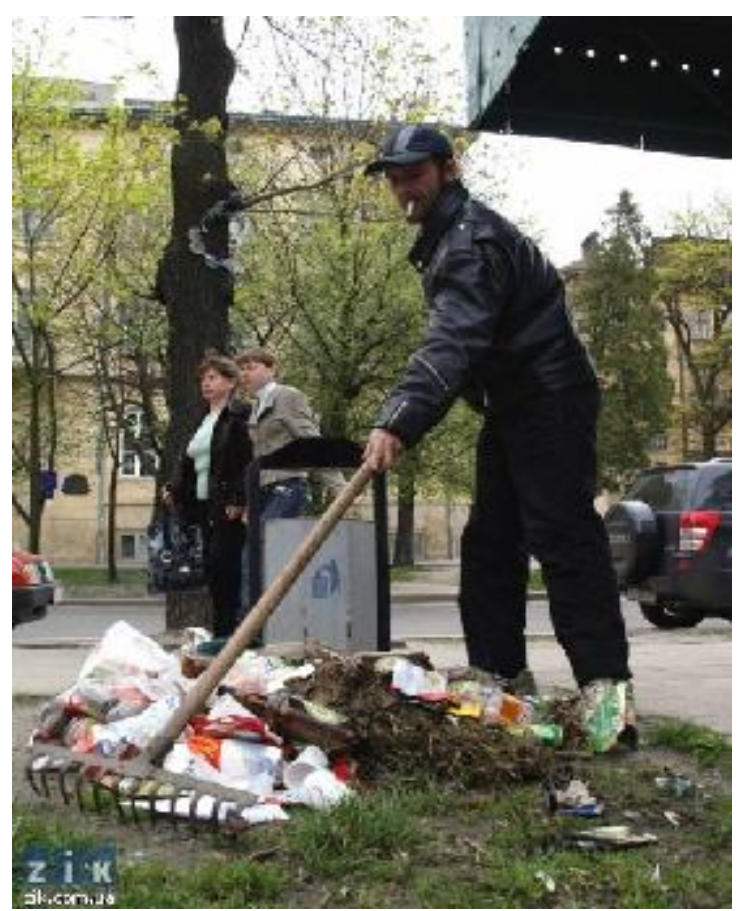

Fotografia 1. Grabienie śmieci; praca. Kontrastowanie ${ }^{7}$ (http://zik.com.ua/pl/news/2008/04/15/133504)

Zdjęcie zostało zrobione z "niskiej” perspektywy, śmieci są na pierwszym planie. W tle widzimy tak zwanych "normalnych" ludzi i samochody (jeden z nich to raczej drogi terenowy samochód marki Suzuki). To, co widzimy na zdjęciu jest elementem procesu, który może zostać nazwanym „kontrastowaniem”. Być może fotograf, razem $z$ widzem (analitykiem) kontrastuje na zdjęciu to, co już jest społecznie skontrastowane. Normalne życie i dobrobyt na tle biedy. Przynajmniej na zdjęciu świat społeczny jest pokazany z tej perspektywy. Widzimy opozycję „bezdomni - normalni” co też jest elementem wizualnego procesu kontrastowania.

Kontrastowanie na drugim zdjęciu zmierza w innym kierunku (zdjęcie 2, Wielkanoc w schronisku). Na pierwszym planie widzimy urzędników siedzących przy stole, którzy przybyli do schroniska by świętować Wielkanoc razem z bezdomnymi. Są oni dobrze ubrani, mężczyzna w garniturze i krawacie, jedna z kobiet ma dwuczęściowy kostium i widoczną biżuterię. Urzędnicy nie siedzą razem z bezdomnymi i rozmawiają między sobą. Między nimi i bezdomnymi jest dzieląca ich przestrzeń stanowiąca niemal centrum fotografii, gdyby zrobić jego planimetryczny podział. W tle widzimy bezdomnych, którzy się rozglądają i nie rozmawiają ze sobą. „Kontrastowanie” jest procesem. Wyławianie różnic jest być może definicją sytuacji fotografa (bezdomny z klubu fotograficznego), jednakże zdjęcia są związane z „realną" sytuacją i społeczno-strukturalnymi relacjami widocznymi na pierwszy rzut oka dla obserwatora-socjologa. Tutaj kierunek patrzenia jest odwrotny w porównaniu z pierwszym zdjęciem - na drugim zdjęciu na pierwszym planie widzimy „normalnych ludzi”, czyli urzędników, a bezdomni są na drugim planie.

\footnotetext{
${ }^{7}$ Podpisy pod zdjęciami są kodami analizującego.
} 


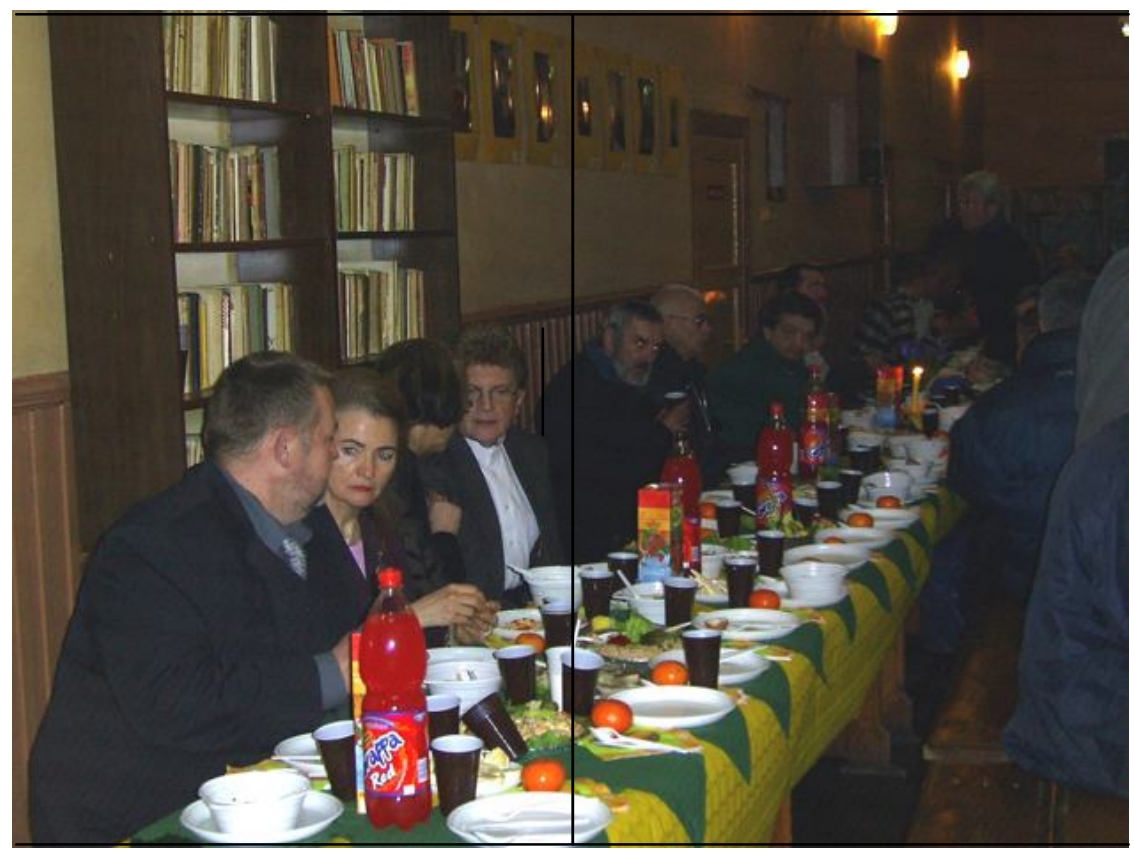

Fotografia 2. Wielkanoc w schronisku, świętowanie Wielkanocy. Kontrastowanie ${ }^{8}$

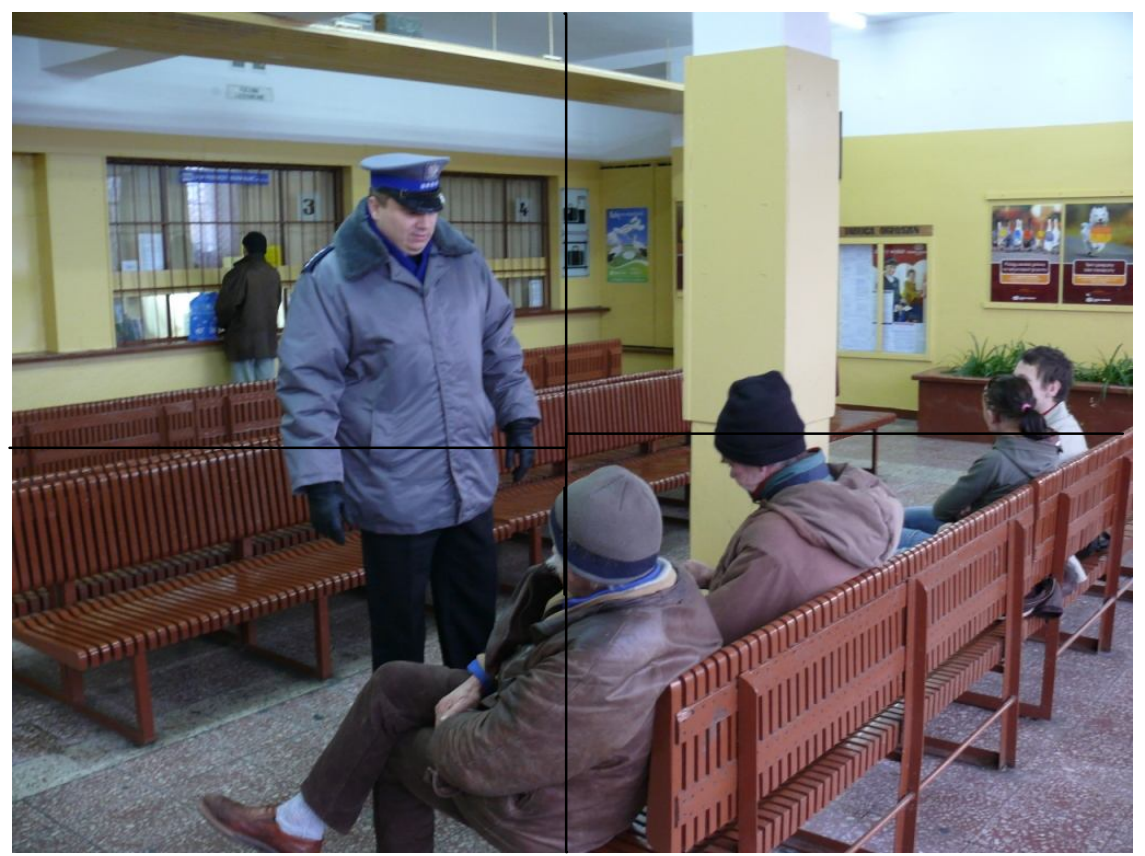

Fotografia 3. "Kontrastowanie" na dworcu; ławka; ławkowanie

"Wizualne kontrastowanie" oficjalnych przedstawicieli prawa z osobami wyglądającymi na bezdomnych jest widoczne na zdjęciu 3. Prawie jedną czwarta zdjęcia zajmuje sylwetka policjanta i jego osobista przestrzeń. Policjant stoi i patrzy na dwie osoby siedzące na ławce, na dworcu. Jeden z nich ma spuszczoną głowę i patrzy w dół, prawdopodobnie szukając dokumentów. Po prawej stronie widzimy "normalnych ludzi", również siedzących, ale na innej ławce. Między nimi stoi słup przydający znaczenie oddzielenia. Widzimy przestrzeń dzielącą dwa światy,

${ }^{8}$ Zdjęcia z Wielkanocy $\mathrm{w}$ schronisku pochodzą ze strony internetowej Klubu Fotograficznego "Bezdomni" przy Schronisku św. Alberta w Łodzi, ul. Szczytowa 11 (http://www.bezdomni.ovh.org/easter.html; 01.06.2008). 
„normalni ludzie” siedzą osobno w pewnym oddaleniu od bezdomnych. $\mathrm{Na}$ zdjęciu widzimy również „normalnego" mężczyznę kupującego bilet w kasie. Po raz kolejny mamy do czynienia z bezdomnymi otoczonymi przez tak zwany normalny świat. Kontrastowanie zostało głównie pokazane przez wykadrowanie zdjęcia na policjanta, który prawdopodobnie prosi bezdomnego mężczyznę o dokumenty. Policjant jest główną postacią na zdjęciu, reprezentuje on oficjalny świat. Bezdomni są natomiast „wyrzutkami” kontrolowanymi ponieważ nie mają domu i są łatwo rozpoznawalni nie tylko przez policję. Ta rozpoznawalność dotyczy pewnych cech wyglądu i zachowań. $\mathrm{Na}$ fotografii niekoniecznie muszą siedzieć bezdomni, ale tak wyglądają i tak zostali rozpoznani przez analizujących sytuację studentów. Na zdjęciu możemy zaobserwować ponadto opozycję stanie - siedzenie (policjant - bezdomny).

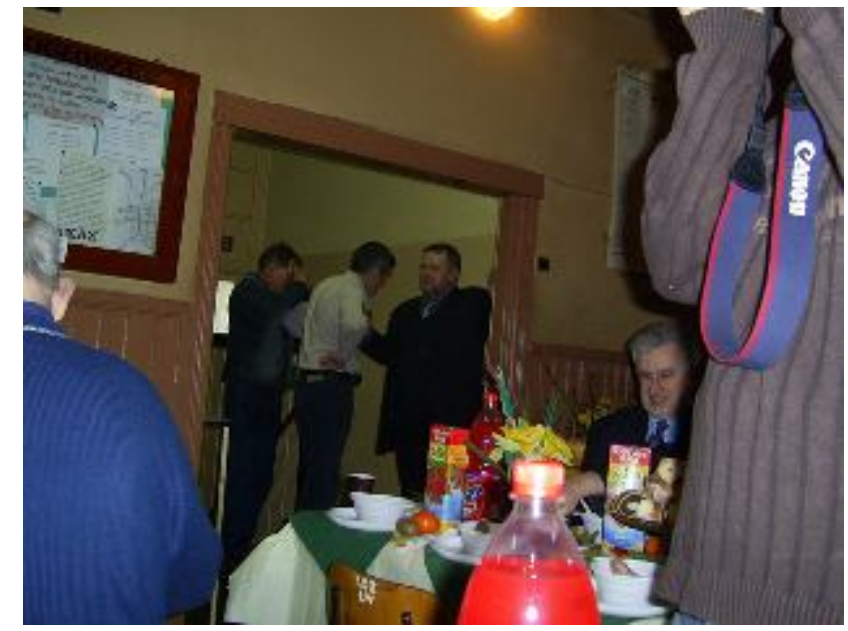

Fotografia 4. Kontrastowanie; drzwi jako linia podziału między sceną i kulisami; jedzenie; praca fotografa; świętowanie Wielkanocy (http://www.bezdomni.ovh.org/easter.html)

$\mathrm{Na}$ zdjęciu $4 \mathrm{w}$ tle widzimy bezdomnego wykonującego zdjęcia. $\mathrm{Z}$ tej perspektywy widzimy także zakulisową dyskusję oficjeli. Otwarte drzwi dzielą scenę, gdzie trwa świętowanie i przestrzeń za sceną - kulisy. Widzimy oficjeli i bezdomnych fotografów, którzy poprzez robienie zdjęć w określony sposób pokazują co jest dla nich ważne. Kontrast tych dwóch społecznych światów jest najbardziej interesującą rzeczą wynikającą z podziału przestrzeni na scenę i kulisy.

Patrząc dalej na sekwencję zdjęć możemy odnieść wrażenie „atmosfery czekania" (jest to interpretacja analizujących fotografie), ale bardzo specyficznej, ponieważ nie jest to czekanie na coś konkretnego, określonego. Bezdomni wydają się nie mieć co robić, choć „siedzenie” jest dla nich ważną czynnością, bowiem zdarza się im często. „Siedzenie na ławce” wydaje się być jedną z taktyk przetrwania dnia a także sytuacji „bezdomności”, a więc jest ważną dla nich aktywnością. Zdjęcie 5 pokazuje bezdomnych siedzących na ławce. Jeden czyta gazetę, drugi bez koszulki (prawdopodobnie jest gorąco) pali papierosa (widzimy jego długość, jak bardzo jest już wypalony), a trzeci ze zdeformowaną głową patrzy w obiektyw. Atmosfera wydaje się być wakacyjna, jednak to, co widzimy po bliższym przyjrzeniu się to ławka przed schroniskiem, gdzie raczej nie ma wakacji, tylko „ciągłe bezdomne życie." 


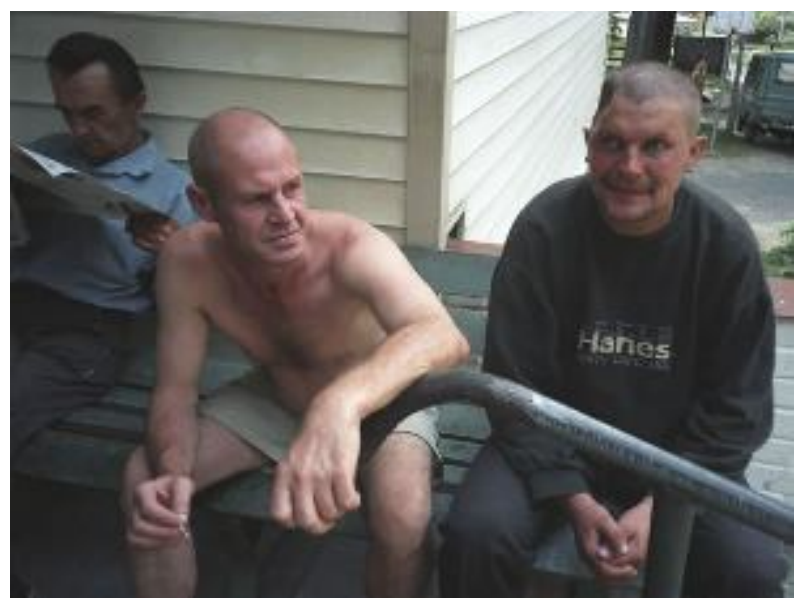

Fotografia 5. "Atmosfera czekania"; odpoczywanie - na ławce, ławkowanie, Miejsce siedzenia

„Jedzenie i spanie” są własnościami „atmosfery czekania” (patrz zdjęcie 6). „Atmosfera czekania” z kolei jest prawdopodobnie własnością „atmosfery życia bezdomnych". Na omawianym zdjęciu nie ma wyraźnej opozycji, kontrastowania. Świat bezdomności jest wewnętrznie spójny i życie toczy się powoli i „spokojnie”.

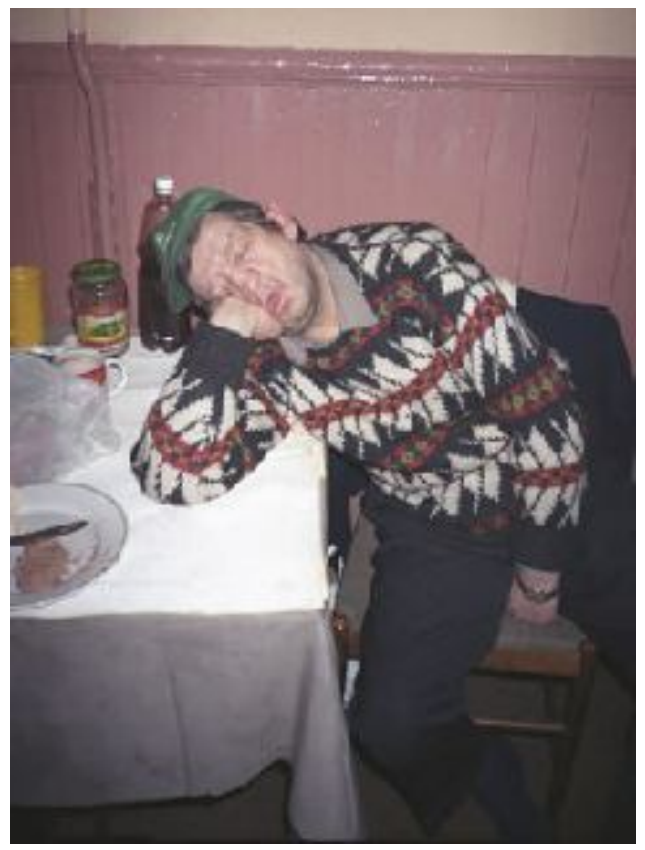

Fotografia 6. Bezdomny śpiący na stole. "atmosfera czekania”, jedzenie, "jedzenie i spanie"

Atmosfera czekania jest także zjawiskiem grupowym (patrz zdjęcie 7). "Siedzenie na ławce" jest to bardzo ważny elementem życia bezdomnych i „atmosfery czekania”. „Zabijanie czasu” jest pewnym wymiarem atmosfery czekania (zdjęcie 7). Możemy to zaobserwować na wielu zdjęciach. Ławka jest związana z czekaniem, jak to się dzieje zwykle na dworcu (porównaj zdjęcie 3), jednak bezdomni nie czekają na coś konkretnego, czy wyjątkowego. Ławka jako przedmiot i element przestrzeni nakłania do konkretnej czynności nazwanej przez nas „ławkowaniem” (własność „atmosfery czekania”). Bezdomni po prostu siedzą i czekają, obserwują, bowiem muszą coś robić istniejąc w czasie. Borykanie się 
z upływającym czasem, który dany jest naocznie i bezpośrednio jest trudnym zadaniem - „trzeba zabić jakoś ten czas” (zob. fotografię $38 \mathrm{w}$ Załącznikach) ${ }^{9}$. To siedzenie i czekanie zawsze (na fotografiach) jest związane z pochylaniem ciała do przodu i trzymaniem łokci na kolanach lub udach. Taka pozycja daje wrażenie zmęczenia, rezygnacji, brak jest uśmiechu lub jest on ledwie zaznaczony. Nie ma zdjęcia pokazującego bezdomnego siedzącego prosto, bez podparcia o kolana lub uda, z pełnym oparciem o poręcz krzesła lub ławki. Być może jest to związane z ergonomią siedzenia, ale sądzimy, że ma to związek z ich sytuacją życiową i niepewnością odnośnie aktualnej sytuacji. Jest to pewien choreograficzny idiom ciała ukazujący ich aktualną tożsamość w trakcie fotografowania.

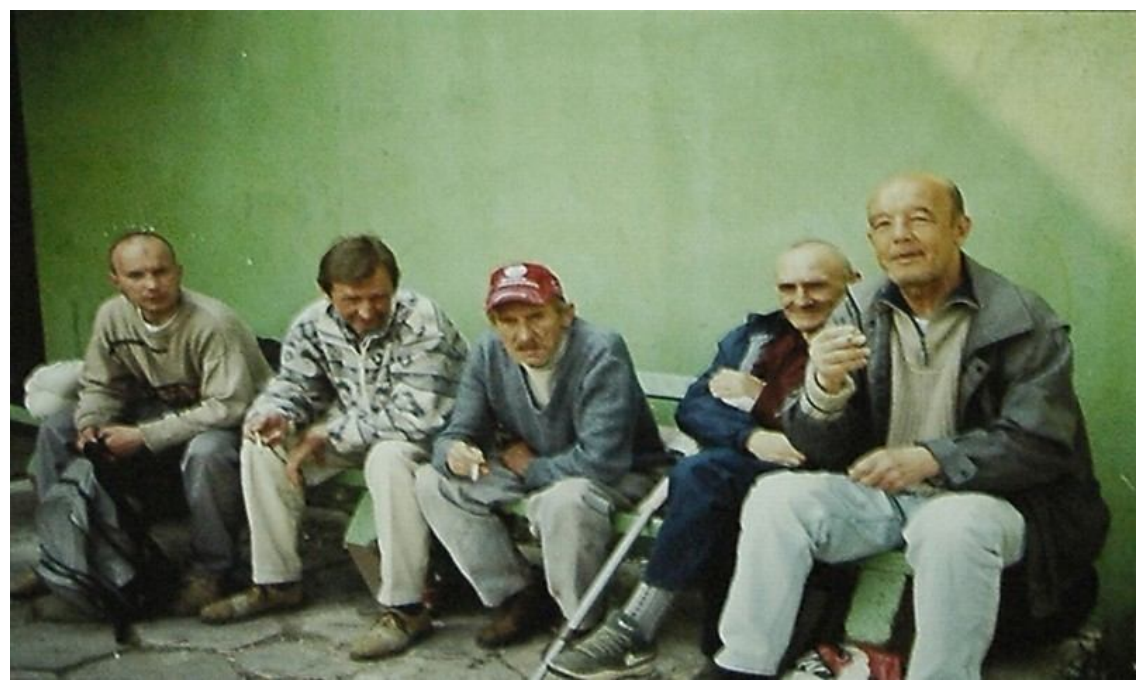

Fotografia 7. Siedzenie na ławce. Ławkowanie. Miejsce czekania. Grupowy charakter "atmosfery czekania". Odpoczywanie - palenie. Bezdomni w różnym wieku, lekko uśmiechnięci, pochylający ciało do przodu, trzymający tokcie na kolanach lub udach. (http://www.Itf.com.pl/wystawy_w_galerii/w_o_obiektyw_bezdomnego.html)

Patrząc na sekwencje zdjęć odnajdujemy wzory. Oprócz „atmosfery czekania” możemy wygenerować kategorię: „koncentracja na jedzeniu”. Wiele zdjęć pokazuje jedzenie, czynność jedzenia lub jedzenie w tle kiedy fotografowana jest inna czynność. Jedzenie jest kojarzone z wieloma innymi czynnościami. Na zdjęciu 6 widzimy żywność ukazaną na brzegu fotografii - mężczyzna śpi po jedzeniu. Zdjęcie 8 pokazuje samą czynność jedzenia. Zdjęcie 9 ukazuje koncentrację fotografa na żywności, rozdawanej podczas akcji dobroczynnej.

\footnotetext{
${ }^{9}$ Podobną atmosferę oczekiwania można było zaobserwować w społeczności opisanej przez autorów sławnej pracy o bezrobotnych (Jahoda, Lazarsfeld, Zeisel 2007). Bezrobotni - mężczyźni poruszali się wolniej od kobiet, częściej zatrzymywali się spacerując, wg autorów dużo „próżnowali”. „Dla mężczyzn podział na godziny dawno stracił sens. Pobudka, obiad i pójście do łóżka to jedyne dzienne punkty orientacyjne, które się zachowały. Między nimi upływa czas i właściwie nie wiadomo, co się wtedy dzieje.” (Jahoda i In. ibidem: 136). Niektórzy bezrobotni mówią: „Dla nas bezrobotnych nie ma już niestety możliwości zajmowania się czymkolwiek" (Jahoda i In. ibidem:139).
} 


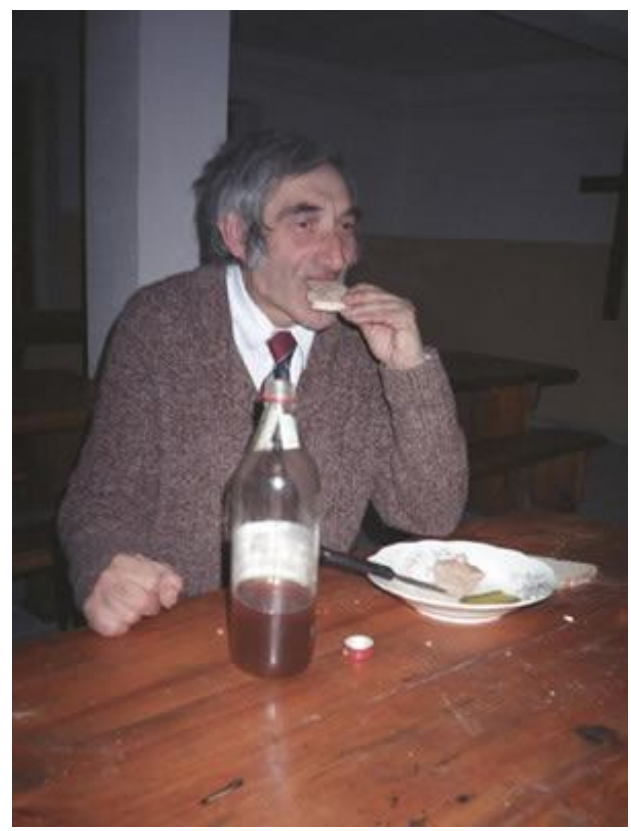

Fotografia 8. Koncentracja na jedzeniu. Jedzenie

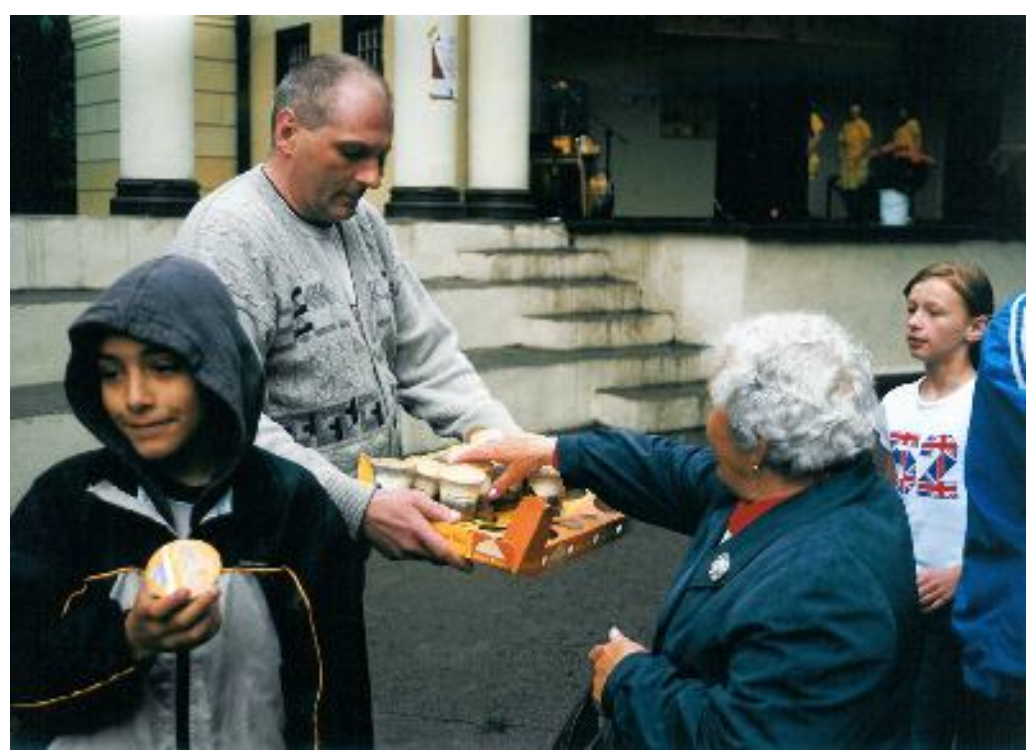

Fotografia 9. Koncentracja na jedzeniu

\section{Dokładny opis fotografii w celu tworzenia nowych kategorii}

Patrząc na sekwencje zdjęć możemy odnaleźć wzory zachowań lub kulturowych układów przedmiotów. Jednakże powinniśmy pamiętać, że sekwencje dające okazje do porównań mogą sprawić, że pewne zdjęcia zostaną nie przypisane do żadnego wzoru. Powinniśmy być bardzo ostrożni, by nie umieszczać ich w jakimś wzorze i w ten sposób na siłę tworzyć dane do istniejących już kategorii. Takie zdjęcia mogą być analizowane oddzielnie i interpretowane tylko na postawie ich zawartości (patrz zdjęcie 10), co pomoże nam stworzyć nowe kategorie i/lub własności.

W pierwszej kolejności powinniśmy zrobić bardzo dokładny opis zdjęcia (patrz poniżej), co zwykle studenci wykonują w grupie, starając się wychwycić wszystkie elementy występujące na fotografii. 
Opis zdjęcia 10. Bezdomny siedzący na łóżku z torbą.

\begin{tabular}{|c|c|}
\hline Opis zdjęcia & \\
\hline $\begin{array}{l}\text { Zdjęcie pokazuje bezdomnego mężczyznę z torbą. } \\
\text { W centrum zdjęcia znajduje się głowa } \\
\text { bezdomnego (widok z podziału planimetrycznego). } \\
\text { Bezdomny się uśmiecha, lekko pokazując zęby } \\
\text { (ma wąsy), patrzy w górę, głowę ma skręconą } \\
\text { lekko w prawą stronę. Siedzi na łóżku po turecku. } \\
\text { W rękach trzyma torbę. Ma zegarek i jest ubrany } \\
\text { we flanelową koszulę. Jest zadbany, ogolony, ma } \\
\text { czyste ręce i paznokcie. W dolnej części zdjęcia } \\
\text { widać kawałek torby i ramę łóżka (przy podziale } \\
\text { horyzontalnym fotografii). Po lewej stronie zdjęcia } \\
\text { widać półkę z przedmiotami (jest to centrum } \\
\text { w planie horyzontalnym). Nad łóżkiem widać część } \\
\text { uchwytów półki. Na półkach przedmioty: zegar, } \\
\text { lampa (? prawdopodobnie), słoik, puszka (? } \\
\text { prawdopodobnie, puszka na herbatę), radio, } \\
\text { "ozdoba - głowa”. Na ścianie wisi zegar (górna } \\
\text { częśc zdjęcia w podziale horyzontalnym - z punktu } \\
\text { widzenia podziału planimetrycznego) z plakatem } \\
\text { (napis na plakacie - 2000). Zegar pokazuje } \\
\text { godzinę 12.28. } \\
\text { Powyżej głowy z lewej strony zdjęcia widzimy } \\
\text { kalendarz z 2003 r. przedstawiający jezioro i las. } \\
\text { Po prawej stronie widzimy powieszone na } \\
\text { wieszaku ubrania (kurtka, koszulka „pod spód” i } \\
\text { prawdopodobnie krótki płaszcz). Dalej na prawo } \\
\text { jest okno, przez które widzimy podświetlone } \\
\text { słońcem liście. } \\
\text { Po prawej stronie zdjęcia powieszony jest ręcznik } \\
\text { (prawdopodobnie) na ramie łóżka (dolny plan } \\
\text { zdjęcia). }\end{array}$ & $\begin{array}{l}\text { Torba (rzeczy osobiste, } \\
\text { własność) } \\
\text { „Wykadrowana głowa” } \\
\text { Uśmiechanie (ekspresja emocji } \\
\text { - zadowolenie) } \\
\text { Siedzenie na łóżku (przestrzeń } \\
\text { prywatna - przestrzeń } \\
\text { publiczna); Trzymanie torby, } \\
\text { zegarek (rzeczy osobiste); } \\
\text { Bycie schludnym. } \\
\text { Rama łóżka - granica } \\
\text { przestrzeni prywatnej; półka - } \\
\text { rzeczy osobiste, przestrzeń } \\
\text { publiczna/przestrzeń } \\
\text { prywatna } \\
\text { Zegar (rzeczy osobiste) } \\
\text { Zegar, czas (rzeczy osobiste) }\end{array}$ \\
\hline
\end{tabular}

Po sporządzeniu opisu zdjęcia i zakodowaniu, możemy napisać notę by lepiej zrozumieć, co się dzieje na tym, pojedynczo analizowanym, zdjęciu ${ }^{10}$. Fotografia ta

\footnotetext{
${ }^{10} \mathrm{~A}$. Clarke sugeruje by pisać tzw. "notę specyfikującą" (specification memo), która pomaga "rozbić ramę" (to break the frame) tak, że widzimy obraz z wielu punktów widzenia. Powinniśmy zatem, zgodnie z Clarke zwrócić uwagę na takie tematy jak: selekcja tego co jest na obrazie, obramowanie, cechy szczególnie uwypuklone, punkty widzenia, światło, kolor, ostrość, obecność/nieobecność pewnych elementów, przewidziani i nieprzewidziani widzowie, kompozycja, struktura, skala i proporcje w danym formacie, techniczne elementy, użycie jednego lub wielu mediów, relacje do innej pracy w danym medium, odniesienia, naprawianie, usytuowanie, relacja do istniejących wizualnych kultur, powszechność/unikalność, praca nad obrazem, zalecenia dla widzów (Clarke 2005: 227 - 226).

Tematy te, szczególnie te dalekie od bezpośredniego oglądu obrazów i mające charakter spekulatywny, jak na przykład relacje do wizualnych kultur uwzględniające socjo-polityczne sytuacje, są bardzo ważne w analizach obrazów usytuowanych w dyskursach, tj. w analizie dyskursu. Badacz, który wykonuje pracę terenową/etnografię powinien bardziej skoncentrować się na kontekście badania i obrazach wytworzonych na miejscu jego badań lub bezpośrednio odnoszących się do pola jego obserwacji.
} 
jest bardzo znacząca gdy się weźmie pod uwagę analizę warunków życia bezdomnych w schronisku.

\section{Nota do zdjęcia 10. „Bezdomny mężczyzna z torbą siedzący na łóżku” Brak podziału na przestrzeń prywatna i publiczna. Rzeczy osobiste, własność}

Jeżeli weźmiemy pod uwage podział publiczne-prywatne widzimy na zdjęciu pomieszanie przestrzeni prywatnej i publicznej. Ubrania bezdomnego wiszą na wieszaku w tle i są widoczne dla wchodzących do pomieszczenia. Podobnie jest z ręcznikiem wiszącym na ramie łóżka. Prawa strona fotografii (podzielonej pionowo na dwie części) pokazuje rzeczy prywatne, które zazwyczaj w naszej kulturze są trzymane w przestrzeni prywatnej i nie wystawiane na widok publiczny. Zazwyczaj nie pokazujemy obcym wnętrza naszej szafy.

Po lewej stronie zdjęcia (blisko obiektywu) widzimy rzeczy osobiste publicznie widoczne (półka z rzeczami). Możemy zaobserwować tzw. „durnostojki” - przedmioty dekoracyjne $w$ naszych domach, które są zazwyczaj stawiane na kominkach, półkach, wgłębieniach $w$ ścianie $i$ tym podobne. Są to przedmioty mające pokazywać naszą tożsamość szerszej publiczności. Większość przedmiotów w schronisku ma charakter funkcjonalny (zegar, radio, lampa), chociaż są też niektóre dekoracyjne (ozdoba-głowa).

Przestrzeń prywatna jest zmieszana z publiczną. Bezdomni mają niewielkie szanse na utrzymanie swoich prywatnych rzeczy z dala od oczu innych osób. Jedyną zamkniętą prywatną przestrzenią jest torba, którą bezdomny trzyma $w$ rękach. Reszta przedmiotów, nawet tych umieszczonych daleko od obiektywu, jest dostępna i możliwa do zaobserwowania dla innych, co zostało udokumentowane na fotografii.

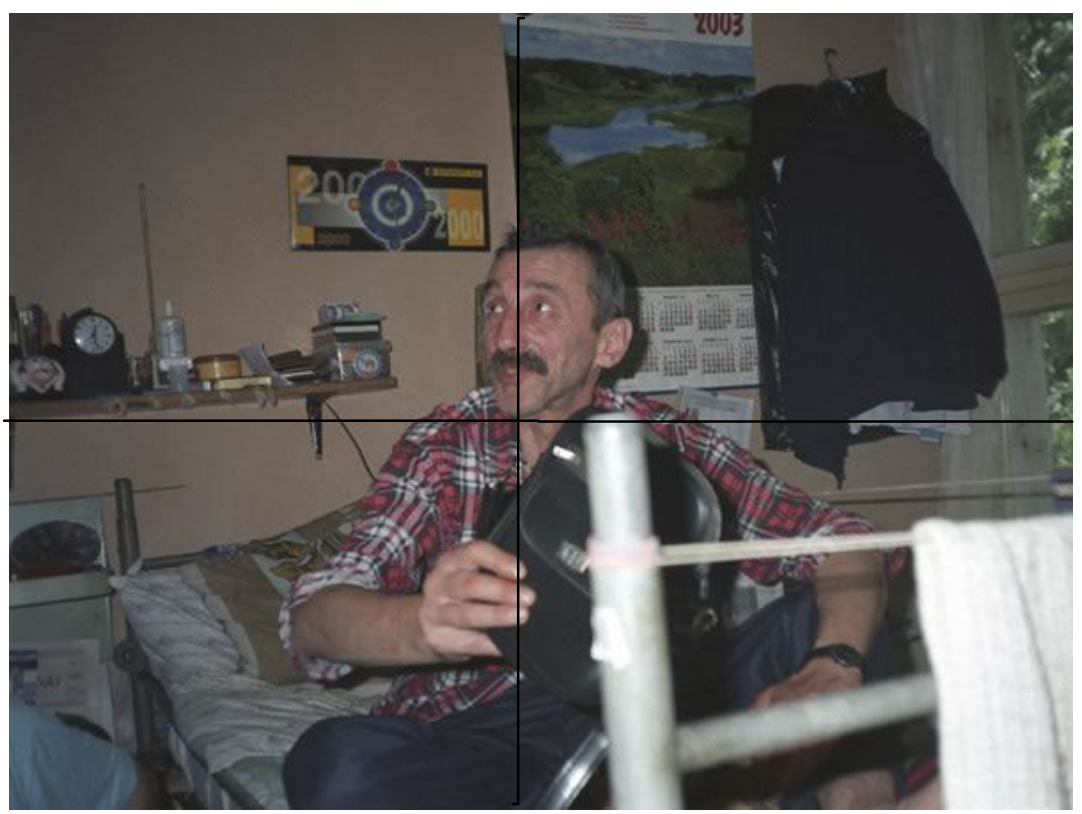

Fotografia 10. Bezdomny siedzący na łóżku z torbą; łóżkowanie; bycie zamkniętym w przestrzeni ciasnota 


\section{Porównanie w celu generowania bardziej ogólnych pojęć}

Studenci mogą być również inspirowani do bardziej ogólnego myślenia poprzez dostarczenie im sekwencji zdjęć z innych kontekstów mających pewne analogiczne podobieństwa (otwarte - analogiczne porównywanie).

Jeśli porównamy zdjęcia bezdomnych i przedsiębiorcy lub managera wyższego szczebla możemy znaleźć pewne społeczne kalki do interpretacji różnic (patrz zdjęcie 11). Socjologowie zazwyczaj myślą w kategoriach społecznej stratyfikacji lokując ludzi w określonej kategorii. Studenci powinni również mieć na uwadze kulturowe wzory pozycji ciała w odniesieniu do przynależności klasowej lub warstwowej.

Mówiliśmy, że bezdomni na fotografiach zazwyczaj mają głowy pochylone i łokcie oparte na kolanach lub udach. Ta pozycja ukazująca zmęczenie, (może być także spowodowana naturalna biomechaniką ciała) może zostać skontrastowana z wyprostowaną postawą managera wyższego szczebla.

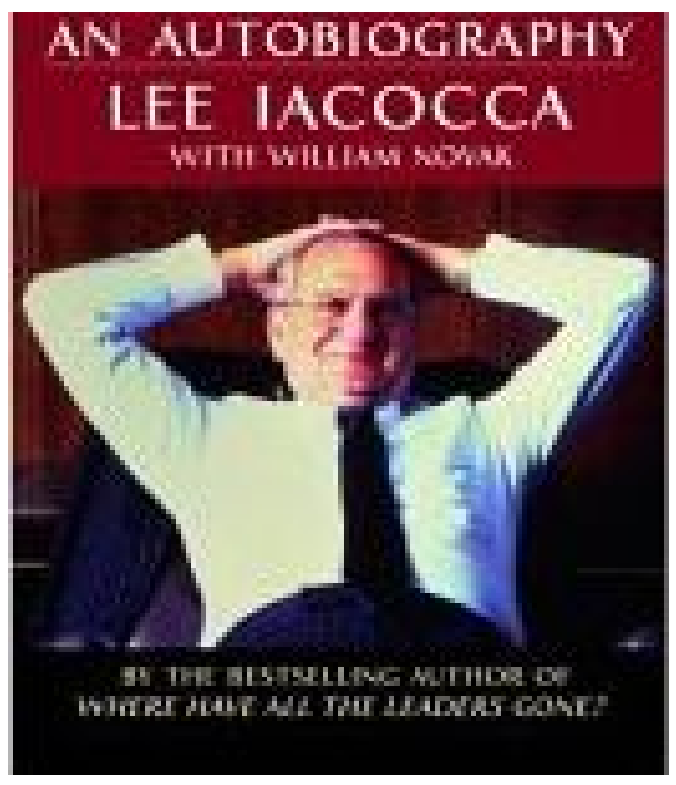

Fotografia 11. Lee lacocca z okładki swojej autobiografii, "pozycja dominująca", asertywność, "formalny-nieformalny" wzór autoprezentacji (lacocca, Novak 1984).

Bardzo znacząca jest okładka książki, na której autor, manager Lee lacocca, prezentuje się $w$ bardzo asertywnej pozie, $\mathrm{z}$ rękami za głową, uśmiechając się do fotografa (bez otwierania ust) i patrząc bezpośrednio na niego (i tym samym na widza). Jest bez marynarki, ale w krawacie, co sugeruje formalność i jego pozycję w biznesie. Stwarza w ten sposób dystans do obserwatora. Wydaje się, że tylko uznany w świecie człowiek może pogodzić nieformalny styl autoprezentacji z formalnym, i w tej sytuacji rozbieżne style prezentacji stają się społecznie akceptowane. Lee lacocca patrzy na widza - fotografa asertywnie by pokazać, że alter-ego nie należy do tego świata. Taki „formalny-nieformalny” wzór autoprezentacji jest możliwy do osiągnięcia jeśli ktoś jest doświadczonym profesjonalistą z wieloma sukcesami w jakiejś branży, a szczególnie w biznesie (Mastenbroek 2000).

Jeżeli dodamy zdjęcie 11, ukazujące sławnego managera, do sekwencji poprzednio analizowanych zdjęć bezdomnych, nasza analityczna perspektywa ulega zmianie. Studenci zaczynają myśleć o klasowo generowanych formach wizualnej 
prezentacji określonej pozycji społecznej. Porównując zdjęcia 10 i 11 widzimy dwóch uśmiechniętych mężczyzn, lecz uśmiechających się w różnych kontekstach. Uśmiech bezdomnego jest skromny. Ta interpretacja pochodzi ze sposobu w jaki trzyma torbę - blisko ciała, siedząc na łóżku w schronisku wkomponowany jest w niewyraźny podział na przestrzeń prywatną i publiczną. Manager z kolei siedzi na fotelu i jego „nieformalność” została zaaranżowana by pokazać jego wyższość. lacocca nie pokazuje zębów, gdy się uśmiecha, bezdomny je pokazuje. Spojrzenie bezdomnego nie jest skierowane prosto w obiektyw, podczas gdy manager patrzy prosto na fotografa.

Ta krótka sekwencja dwóch fotografii pokazuje społeczne tło reprezentujące pozycję społeczną. Wzory te są stworzone nie tylko przez zachowania fotografowanych, lecz także przez fotografa. W przypadku bezdomnych, fotografami byli również bezdomni, dlatego prezentacja pozycji społecznej bazowała na perspektywie samych aktorów społecznych. Fotografowie patrzyli na kolegów tak, jak postrzegają samych siebie.

Bez stworzenia nowej sekwencji i dodania zdjęcia Lee lacocca, studenci mogliby nie wygenerować nowego wzoru interpretacji. Sztucznie stworzona sekwencja jest narzędziem analizy i równocześnie narzędziem dydaktycznym do rozpoczęcia analizy wzorów i ogólnych kategorii w tym przypadku: sposobów autoprezentacji w powiązaniu z pozycją społeczną.

\section{Nasycanie kategorii i teoretyczne pobieranie próbek}

Nasycanie kategorii oznacza poszukiwanie możliwych własności jakiegoś pojęciowo oznaczonego zjawiska. Jeżeli przykłady wskazują pewne własności, które powtarzają się cały czas podczas zbierania danych i analizowania ich, badacz czuje, że kategoria jest nasycona (zob. dyskusję na ten temat w Charmaz 2009). Teoretyczny opis kategorii może być dopracowywany w pojęciowych szczegółach. Generując wizualną teorię ugruntowaną aby nasycić kategorię, powinno się poszukiwać zdjęć z różnych kontekstów. Powinniśmy zatem dokonać teoretycznego pobierania próbek, to znaczy szukać różnorodnych kontekstów, które mogą dostarczać danych w celu stworzenia całkowitego teoretycznego spektrum występowania danego zjawiska. Szukamy nowych danych w celu porównywania ich i generowania nowych własności dla nasycenia kategorii. Poszukiwanie obrazów czy fotografii lub wykonywanie nagrań wideo z różnych kontekstów występowania danego zjawiska pozwala znaleźć nowe własności kategorii (Schubert 2006). Teoretyczne pobieranie próbek zachodzi cały czas podczas analizy danych, kiedy formułujemy nowe pytania teoretyczne. Analiza jest dokonywana w grupie razem ze studentami, dlatego mają oni możliwość zaobserwowania pracy analitycznej bezpośrednio.

Można zatem nasycać kategorie za pomocą danych i własności pochodzących z fotografii, które zostały dobrane w jakiś sposób podczas teoretycznego pobierania próbek. Pewne kategorie mogą zostać lepiej przeanalizowane za pomocą tego rodzaju danych, na przykład fizyczne warunki życia bezdomnych. Kategoria ta jest szeroka, jednakże sekwencja dobranych zdjęć jest idealne dopasowana do opisywania tej kategorii (patrz dalsze fotografie). Studenci mogą zauważyć, że pewne dane, wybrane spośród konkretnych kontekstów, mają coś wspólnego i poprzez użycie metody ciągłego porównywania konstruują pewne ogólne wzory interpretacji (homologiczne porównania). 
Ta bardzo szeroka kategoria może zostać zatem nasycona dzięki danym pochodzącym z tak dokładnie analizowanych fotografii. Na tym samym zdjęciu możemy odnaleźć wiele przykładów wskazujących na różne własności kategorii. Jedno zdjęcie może dostarczyć wielu danych dla analizy i nasycania kategorii.

Omawiana kategoria jest połączona z przykładami, które wskazują na następujące własności: „koncentracja na pożywieniu” (zdjęcie 8, 9, 13), brak podziału na prywatną i publiczna przestrzeń (zdjęcie 10, zob. także nota do zdjęcia 10, oraz fotografie 12,14), "miejsce na odpoczynek” (zdjęcie 5,7), jedzenie (zdjęcie 6,12), „brak przestrzeni - ciasnota” (zdjęcie 12,15), miejsce ucztowania (zdjęcie 2,13); miejsce ławkowania i łóżkowania" (ławka, zdjęcie 5, łóżko, zdjęcie 15,17), brak osobistych przedmiotów i własności prywatnej (dane z wywiadów).

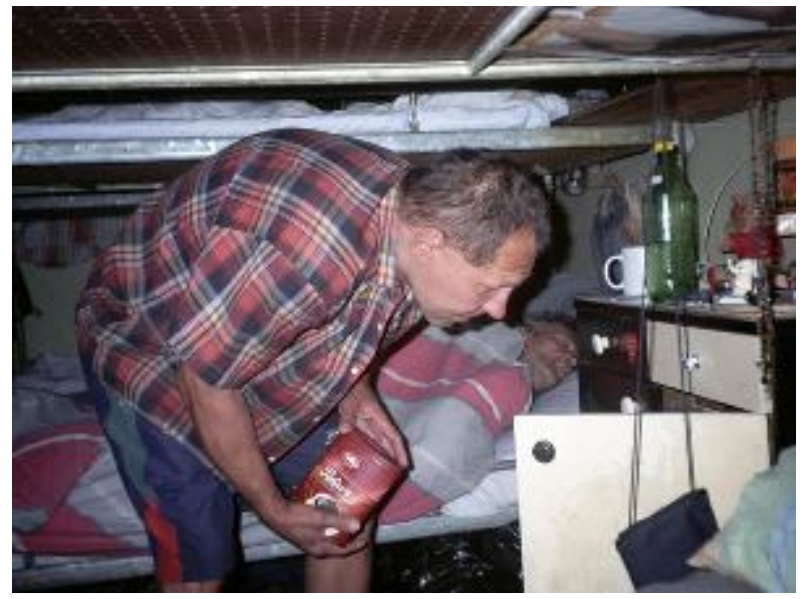

Fotografia 12. Brak przestrzeni - ciasnota; żywność; prywatne przedmioty; ozdoby.

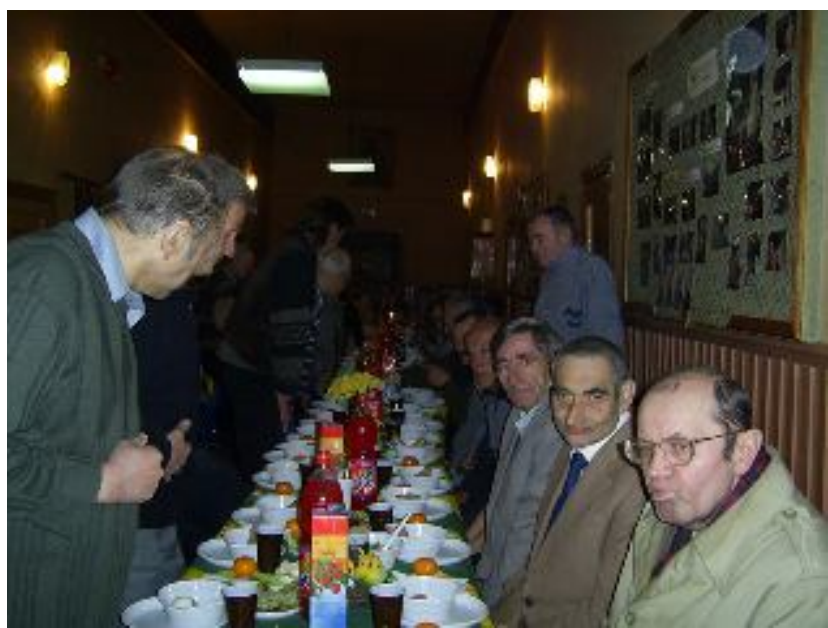

Fotografia 13. Życie w schronisku. Świętowanie Wielkiej Nocy. Stół i miejsce celebracji święta. Zorganizowane świętowanie. Świętowanie i koncentracja na żywności. 


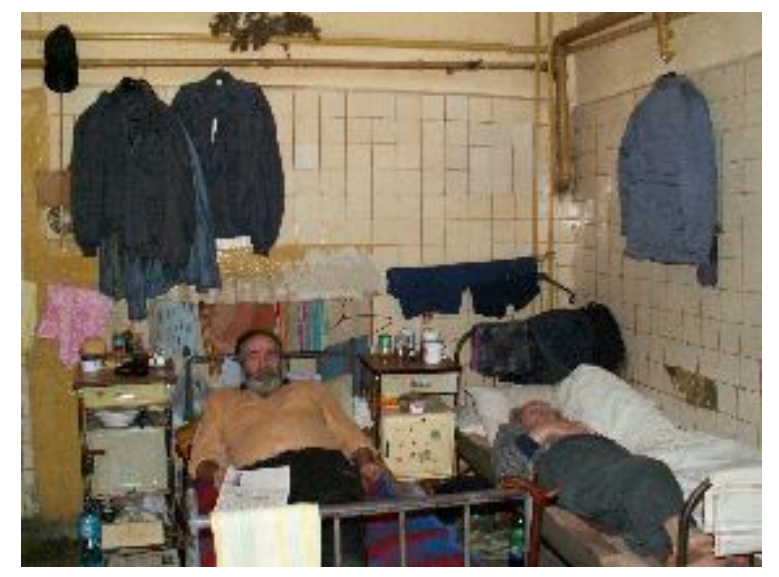

Fotografia 14. Życie w schronisku; problem prywatności; prywatna i publiczna przestrzeń; brak przestrzeni - ciasnota; łóżko; łóżkowanie (fotografia z własnego projektu badawczego, Schronisko Towarzystwa im. Świętego Brata Alberta w Łodzi).

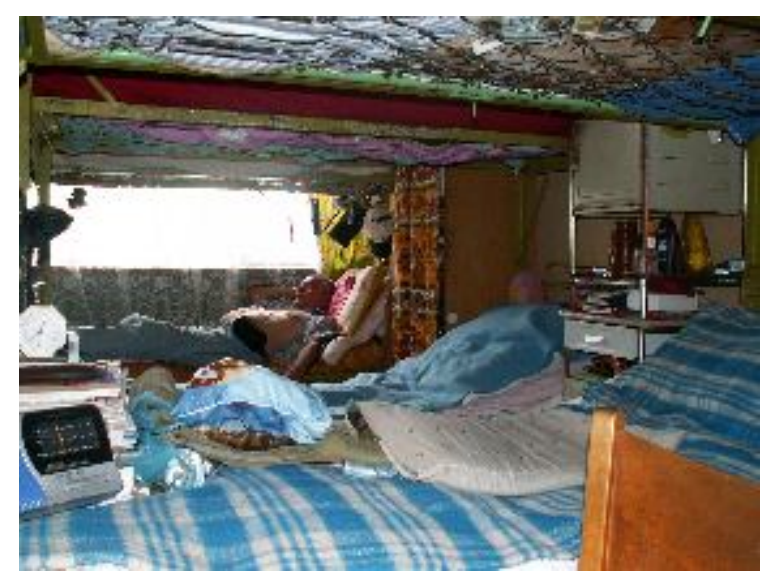

Fotografia 15. Życie w schronisku; prywatna i publiczna przestrzeń; brak przestrzeni - ciasnota; łóżko; łóżkowanie, prywatna własność (fotografia z własnego projektu badawczego, Schronisko Towarzystwa im Świętego Brata Alberta w Łodzi).

Fotografie 14 i 15 wskazują na własność „brak przestrzeni - ciasnota”. Możemy znaleźć więcej fotografii, które wskazują na brak przestrzeni w schronisku. Wszystkie fotografie ze schronisk pokazują przedmioty, które są własnością bezdomnych w pobliżu ich łóżek a nawet na ich łóżkach. W pokojach w wyżej pokazywanym schronisku śpi po czternaście osób i „każdy chciałby mieć własny pokój”, jak powiedział jeden z rozmówców.

Jednym z najważniejszych przedmiotów wskazywanych do fotografowania przez bezdomnych, jest łóżko. Nie ma prawie żadnych prywatnych przedmiotów wskazanych do fotografowania. Łóżko staje się centrum prywatnego życia, chociaż, jak wspomnieliśmy, ta prywatna przestrzeń może być szybko zmieniona na publiczną. Poniżej łóżka mieści się często prywatny magazyn (patrz zdjęcie 16). Powinniśmy dodać, że „fizyczne warunki życia” wiążą się z wykonywaniem pewnych czynności (patrz tezy poniżej, które są konsekwencją tezy powyższej):

1. Jeżeli łóżko jest centrum życia, to „łóżkowanie” jest jednym z najważniejszych czynności bezdomnych ludzi. Podobnie jest z ławką, która wywołuje akt „ławkowania”.

2. W konsekwencji, „atmosfera czekania” jest współtworzona przez fizyczne przedmioty oraz przestrzeń życiową, jak również działania wywoływane z kolei przez 
interpretację fizycznego otoczenia, na przykład działanie ławkowania oraz łóżkowania.

Fizyczne warunki życia -> czynności: łóżkowanie, ławkowanie -> atmosfera czekania/zabijanie czasu.

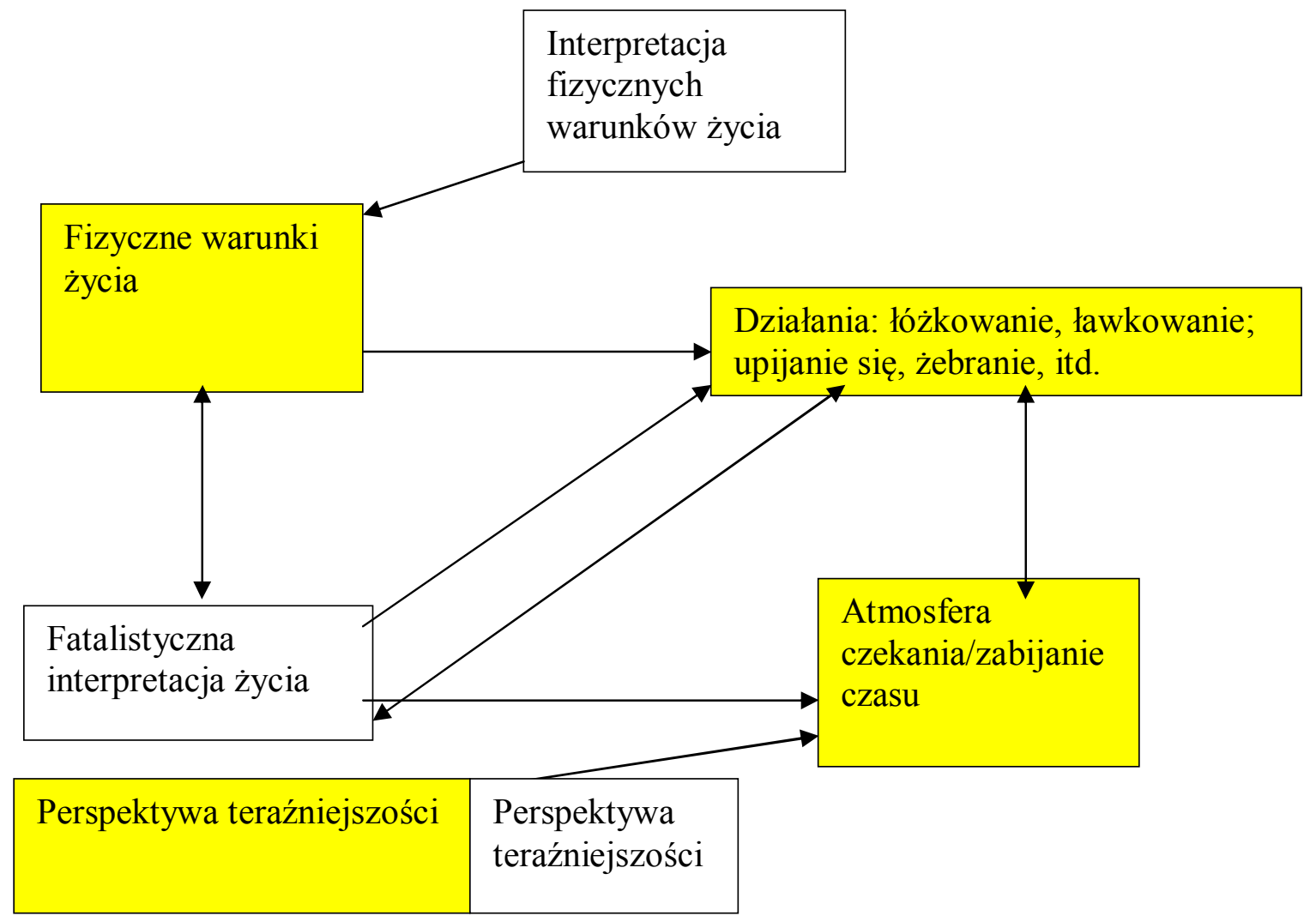

Diagram 1. Powiązania pomiędzy kategoriami (żółte okienka wskazują na wizualne dane użyte dla generowania własności i kategorii; białe wskazują na wywiady jako podstawę dla wygenerowania kategorii).

Ważne jest, że „fizyczne warunki życia” nie stanowią zewnętrznych właściwości życia bezdomnych, nie mogą być one analizowane w izolacji od interpretacji oraz czynności, które się z nimi łączą. Fizyczne warunki życia poprzez interakcję z istotą ludzką przeobrażają się w czyny, na przykład łóżko przechodzi w łóżkowanie, ławka w ławkowanie (zob. także fotografia $38 \mathrm{w}$ Załącznikach). Interakcja z fizycznymi przedmiotami i przestrzenią wytwarza nowy rodzaj działania. Jeżeli ktoś interpretuje swoją przestrzeń życiową jako trudną ale znośną, i/albo nieposiadanie przedmiotów jako wymówkę przed „robieniem niczego ważnego” (to również czynność), wówczas istnieje możliwość „działania biernego” oraz „łóżkowania, ławkowania, odurzania się, żebrania” oraz ostatecznie tworzenia „atmosfery czekania”, która zwrotnie wzmacnia te czynności. 


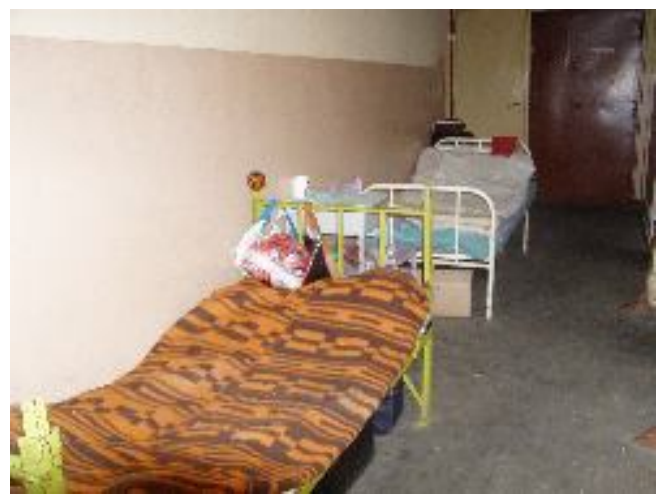

Fotografia 16. Prywatna przestrzeń; własność; centrum prywatnego życia; miejsce łóżkowania (fotografia z własnego projektu badawczego, Schronisko Towarzystwa im Świętego Brata Alberta w Łodzi).

\section{Poza schroniskiem - teoretyczne pobieranie próbek i porównania w celu nasycania kategorii}

Jednakże opisywane przez nas dotychczas fizyczne warunki życia związane są z mieszkaniem w schronisku lub noclegowni. Jeśli wyjdziemy w swych badaniach poza schronisko do innego miejsca zamieszkania bezdomnych, możemy zobaczyć inne strony ich życia codziennego, na przykład miejsce zamieszkania w porzuconych budynkach, lub jak bezdomni przyrządzają jedzenie w ruinach? Jak są ubrani kiedy jest zimno i czy zniszczony dom może ich chronić przed zimnem?

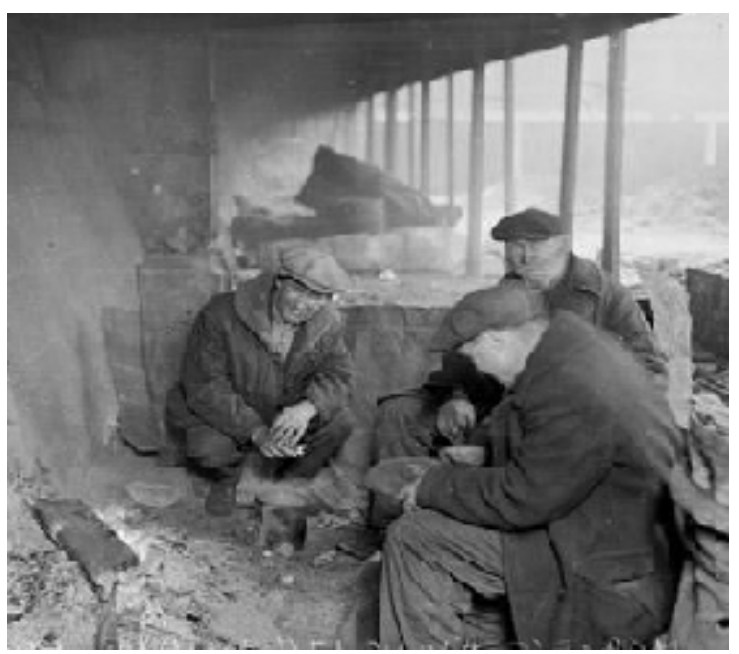

Fotografia 17. Trzej bezdomni - wędrujący (hobos), Chicago, 1929. (http://en.wikipedia.org/wiki/Image:ThreeHobosChicago1929.jpg; 22.08.2008). 


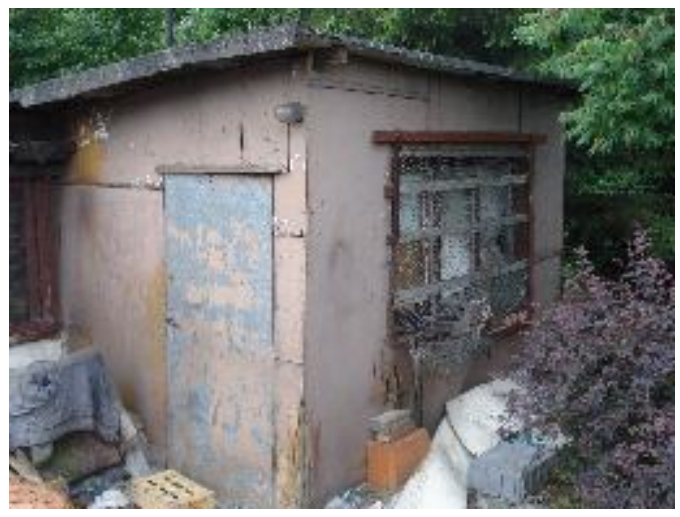

Fotografia 18. Miejsce przebywania bezdomnych - wędrujących, komórka na działce (fotografia z własnego projektu badawczego).

Chcąc odpowiedzieć na powyższe pytania studenci wyszli w teren do bezdomnych przebywających poza schroniskami. Fotografie przez nich wykonane poniżej pokazują miejsca przebywania i „zamieszkiwania” przez bezdomnych wędrujących, przebywających poza schroniskiem.

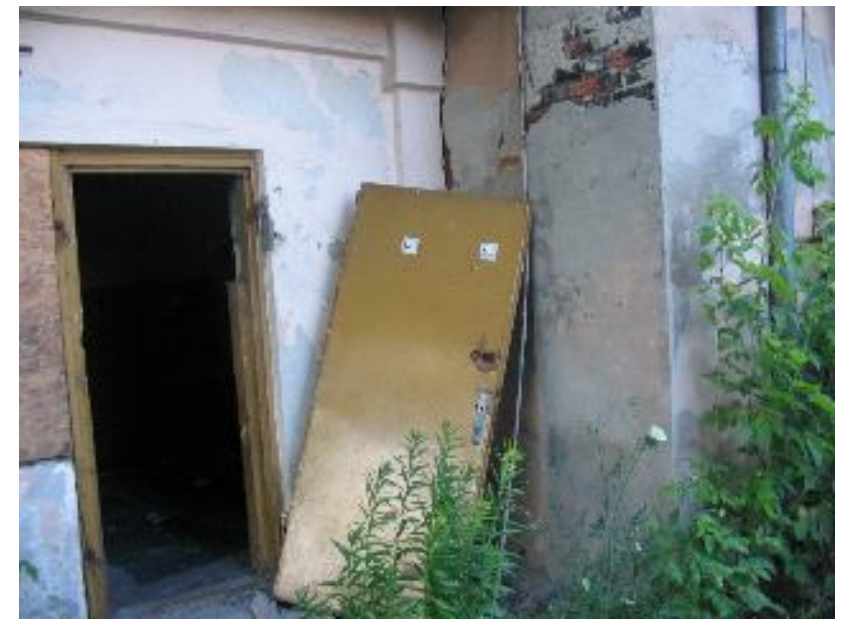

Fotografia 19. Miejsce zamieszkiwania bezdomnych - wędrujących. Ruiny w pobliżu stacji kolejowej Łódź Fabryczna (fotografia z własnego projektu badawczego).

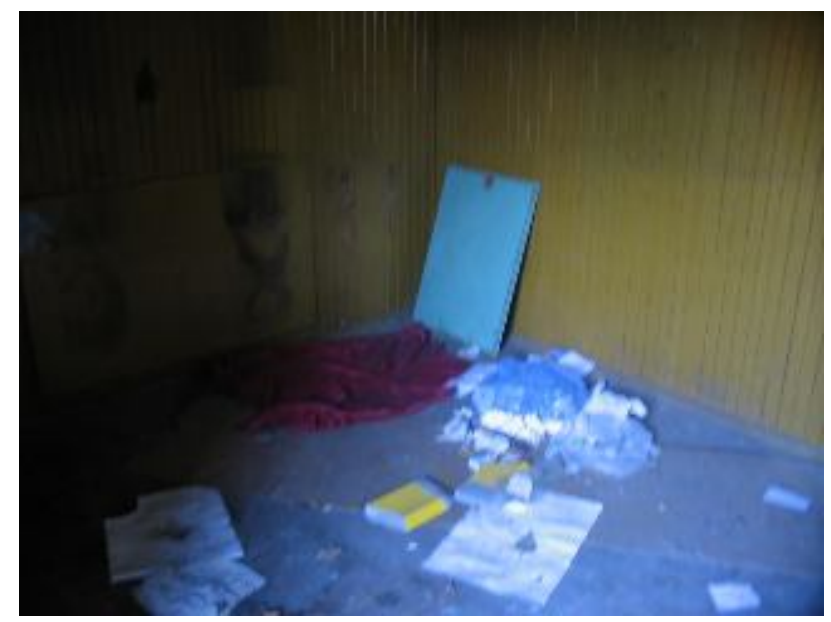

Fotografia 20. Miejsce spędzania czasu podczas deszczu i zimnej pogody w nocy i miejsce na spożywanie alkoholu (fotografia z własnego projektu badawczego). 


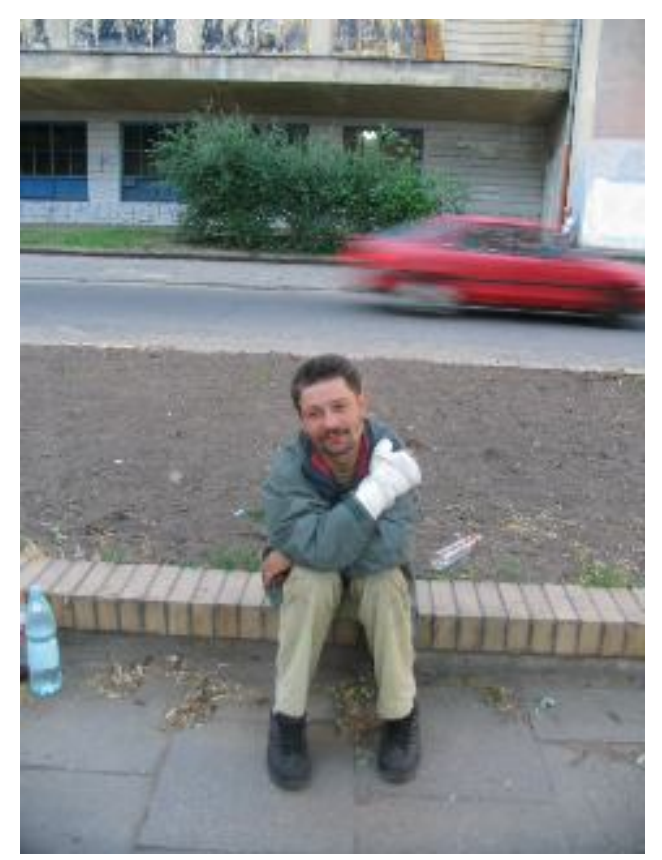

Fotografia 21. Bezdomny mężczyzna, krawężnik, krawężnikowanie, butelka wódki; w pobliżu Wydziału Ekonomiczno - Socjologicznego UŁ (fotografia z własnego projektu badawczego).

Nasycenie kategorii własnościami pochodzącymi z obrazów powinno się zazwyczaj odnosić do danych werbalnych. Powinniśmy zdobyć pewne dane bezpośrednio od bezdomnych aby zrozumieć znaczenia fizycznych warunków życia. Duża część zdjęć, które analizowaliśmy ze studentami, została wykonana przez bezdomnych i znaczenie warunków życia jest zapisane właśnie $w$ reprezentowanych przez zdjęcia fizycznych przedmiotach i przestrzeni. Bezdomni fotografowie oraz „bezdomni kierujący fotografiami” wybrali to, co chcieli pokazać innym (studentom badaczom), co jest dla nich ważne, jak czują i co robią w określonych miejscach.

Studenci pracy socjalnej mogli dzięki temu zdobyć perspektywę na życie bezpośrednio od ludzi, z którymi będą pracować w przyszłości. Nawet zdjęcia mogą stanowić bardzo „uczulające” narzędzia uczące jak prowadzić badania i jak docierać do perspektyw badanych ludzi.

Bezdomni żyjący poza schroniskiem nie mówią zbyt dużo w wywiadzie narracyjnym o swoim obecnym życiu. Przede wszystkim mówią o przeszłości. $\mathrm{Na}$ zdjęciach wręcz przeciwnie, wskazują głównie na aktualne życie. Zdjęcia pokazują przedmioty i przestrzeń z ich teraźniejszego życia: buty, stację kolejową, kosz na śmieci, ulice, szopy, komórki, ruiny, w których sypiają, ławki, na których siedzą lub piją i tak dalej. Informatorzy mówią, że nie posiadają niczego na własność. Bardzo rzadko pokazują na należące do nich przedmioty. Głównie wskazują na przestrzeń oraz społeczne i fizyczne otoczenie życia na ulicach. Ich wizualna wyobraźnia jest ograniczona do obecnych warunków życia, a warunki te są związane przede wszystkim z publiczną przestrzenią w której żyją. Głównie ukazują siebie samych jako samotnych, jak na zdjęciach poniżej, chociaż bezdomny mężczyzna, z którym prowadzono wywiad, żył na ulicy $z$ innym bezdomnym przyjacielem. W schroniskach bezdomni czasami wskazują na swoich przyjaciół jako kogoś godnego sfotografowania. 


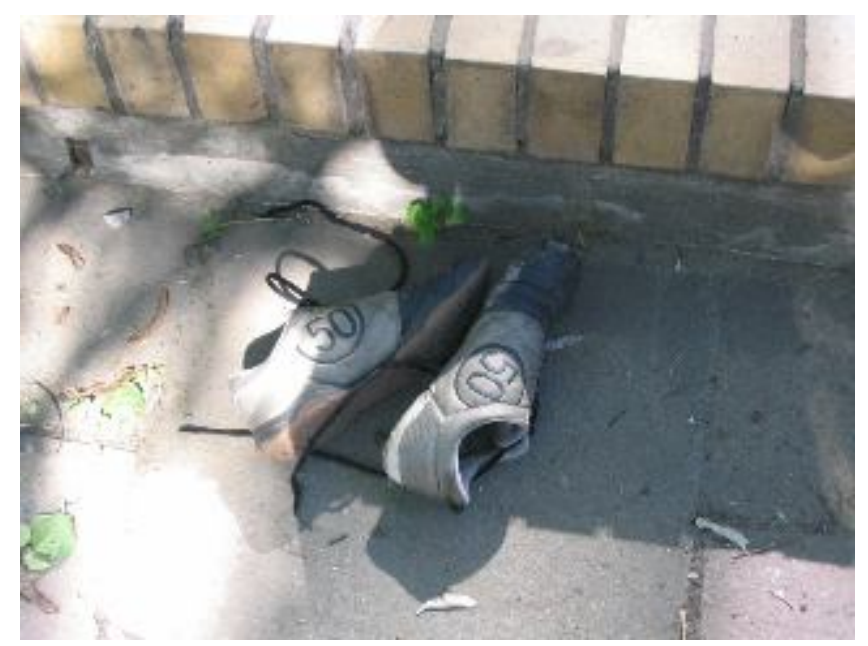

Fotografia 22. Buty. („Mogą się przydać, znalazłem je dzisiaj” (fotografia z własnego projektu badawczego, bezdomny żyjący poza schroniskiem).

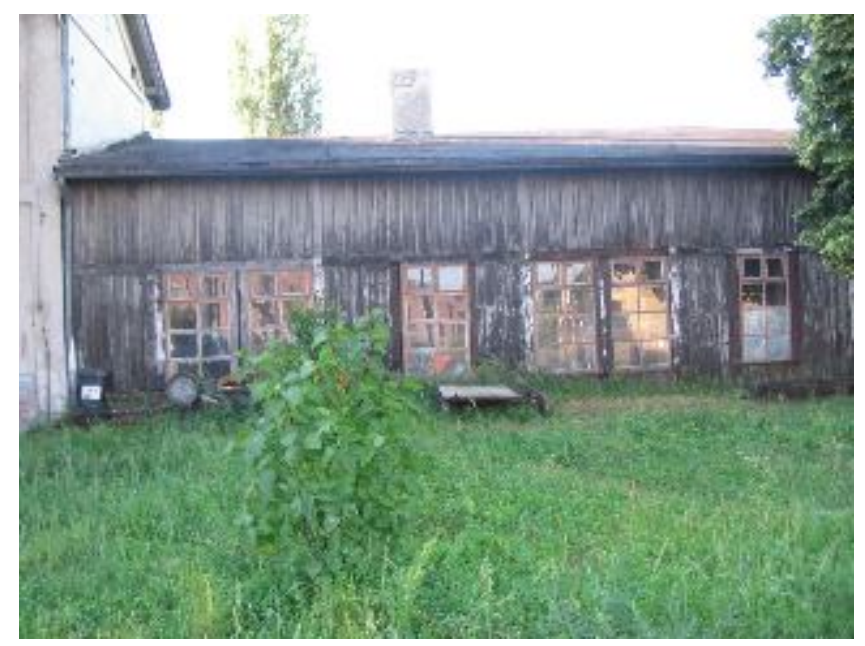

Fotografia 23. Komórki w pobliżu stacji kolejowej. Miejsce „zamieszkiwania” (bezdomni żyjący poza schroniskiem; fotografia $z$ własnego projektu badawczego).

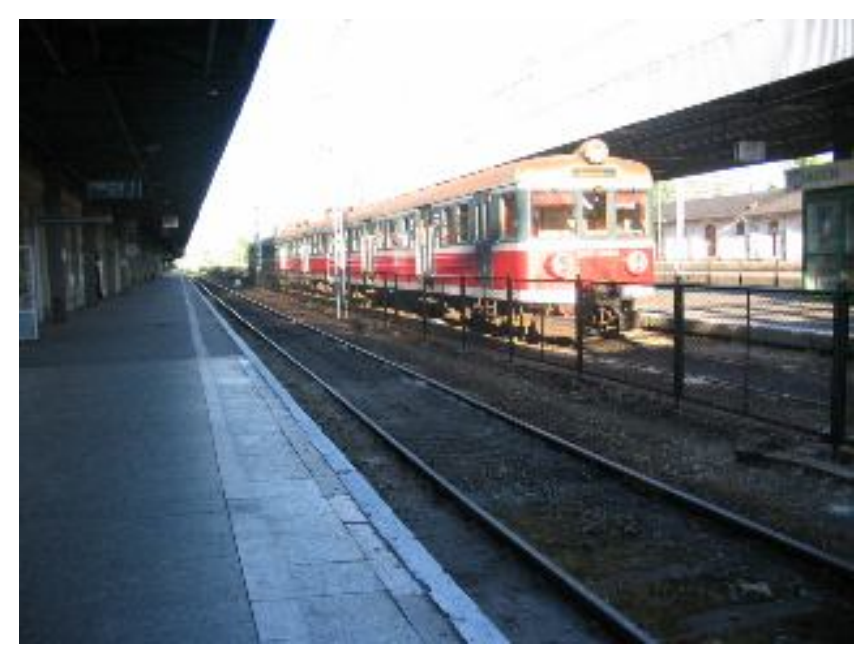

Fotografia 24. Stacja kolejowa Łódź Fabryczna. Miejsce pobytu i życia bezdomnych (bezdomni żyjący poza schroniskiem; fotografia $z$ własnego projektu badawczego). 


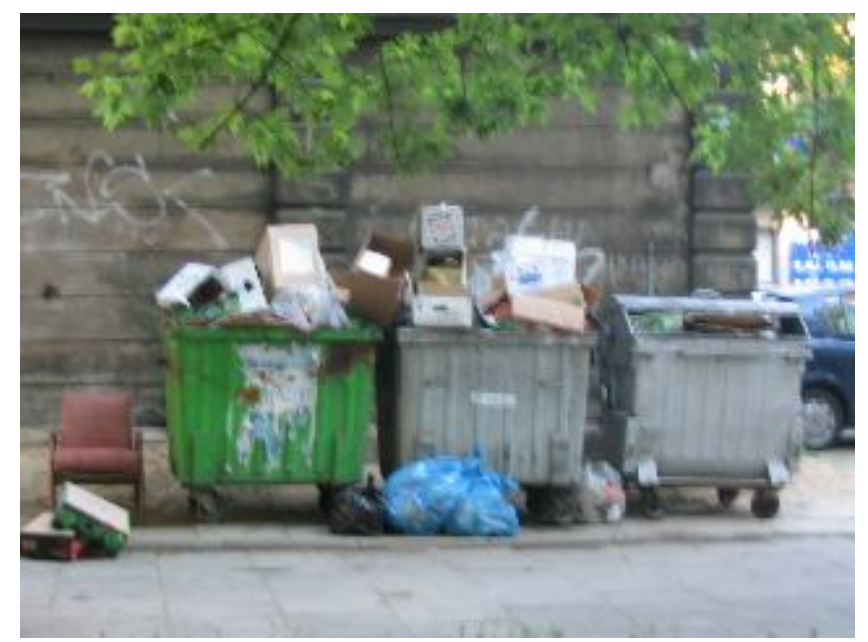

Fotografia 25. Śmietniki dają możliwość uzyskania rzeczy wartościowych i wymienialnych na pieniądze; miejsce pracy bezdomnych (bezdomni żyjący poza schroniskiem; fotografia z własnego projektu badawczego).

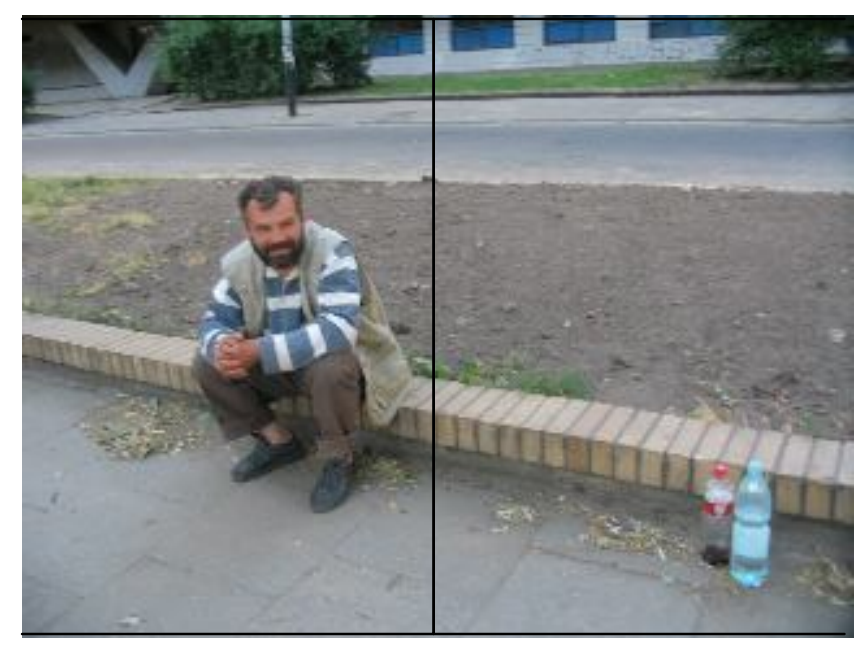

Fotografia 26. Bezdomny siedzący na krawężniku. Fotograf był trochę zakłopotany fotografowaniem i wykonał zdjęcie bardzo szybko nie ogniskując fotografii na twarzy bezdomnego (bezdomni żyjący poza schroniskiem; fotografia $z$ własnego projektu badawczego).

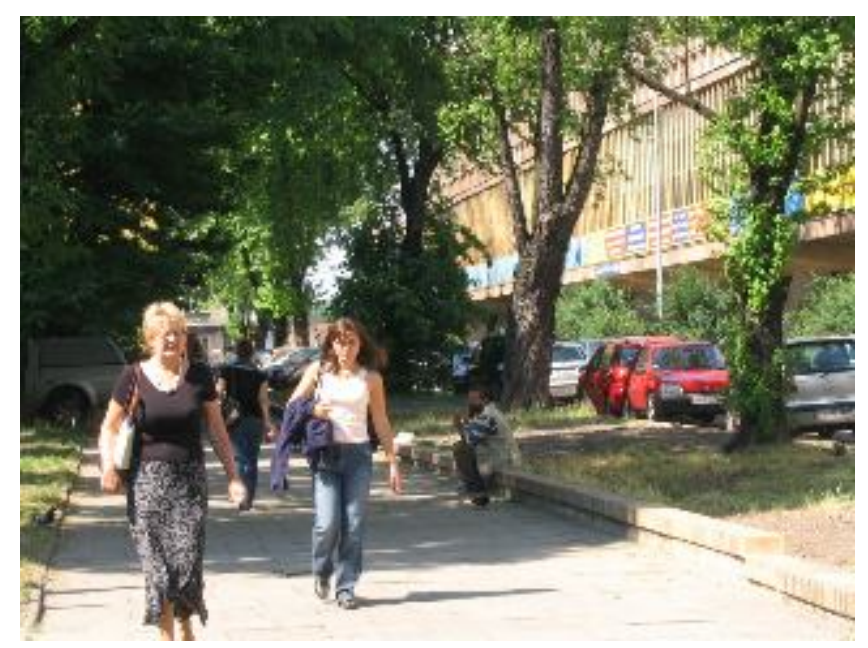

Fotografia 27. Bezdomny siedzący na krawężniku; miejsce w pobliżu Wydziału Ekonomiczno Socjologicznego UŁ (bezdomni żyjący poza schroniskiem; fotografia z własnego projektu 
badawczego). Fotograf był trochę zakłopotany fotografowaniem i zrobił zdjęcie bezdomnemu w tle (porównaj fotografię 26).

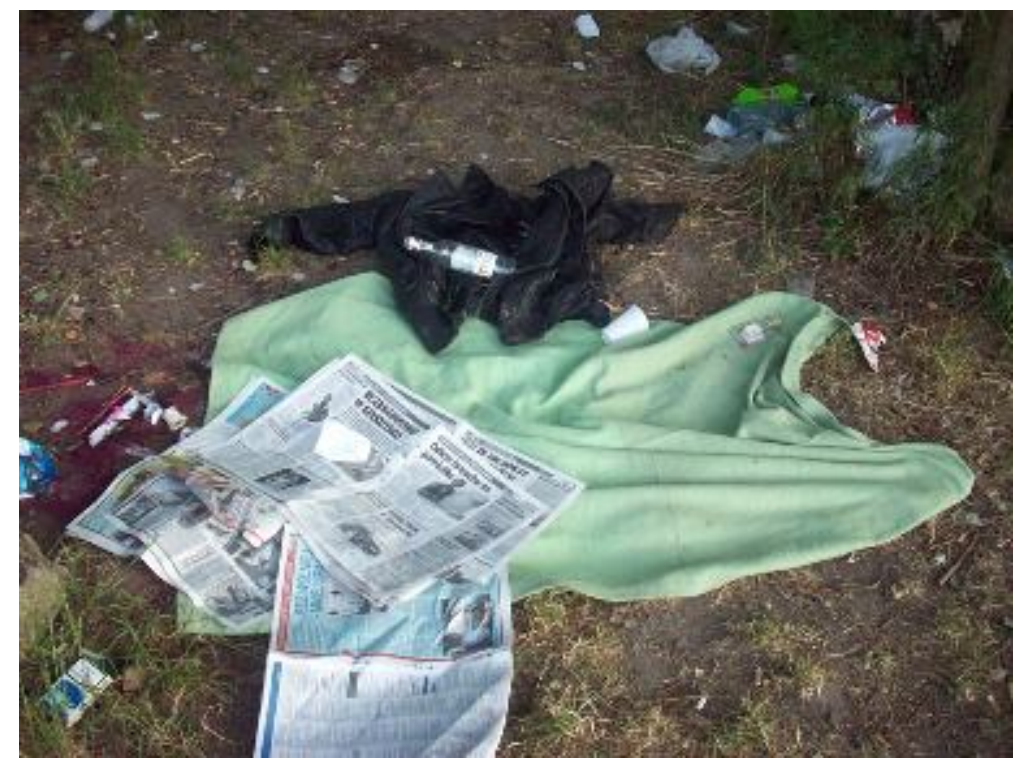

Fotografia 28. Miejsce spędzania czasu. Bałagan, butelka wódki, gazety, paczki po papierosach, miejsce spożywania alkoholu (bezdomni żyjący poza schroniskiem; fotografia z własnego projektu badawczego).

\section{Wizualne kontrastowanie perspektyw czasowych. Współtworzenie sekwencji wizualnych obrazów czasu}

Kategorie są konstruowane podczas badania i analizy danych. Poniższa analiza pokazuje kooperacje badaczy i badanych, wizualne aspekty perspektyw czasowych. Kategoria staje się nasycona poprzez zbieranie danych z różnych kontekstów życia bezdomnych.

Kiedy badacze pytali bezdomnych o pokazanie ich przeszłości, teraźniejszości i przyszłości, bezdomni starali się współpracować i pokazywać ikony tych wymiarów czasu w odniesieniu do swojej historii życia. Czasowość jest osadzona w fizycznych przedmiotach. Posiadanie ich i pokazywanie jest kojarzone $z$ wywoływaniem wspomnień. Jednakże największym problemem dla bezdomnych było pokazywanie przedmiotów, czy też otoczenia, związanych z przeszłością oraz przyszłością. Zazwyczaj nie posiadają oni przedmiotów z przeszłości. Należą one do członków rodziny i tam z nimi zostały. Czasami bezdomni wskazują na swoją przeszłość poprzez pokazanie domów, w których żyli. Domy te przez badaczy zostały sfotografowane (zdjęcie 29, 30, zdjęcia z przeszłego życia). Fotografie te są ikonami przeszłości. Niewielu bezdomnych pokazuje je. Te wizualne ikony kontrastują z aktualnymi i przyszłymi warunkami życia. Obecne życie jest charakteryzowane poprzez kosze na śmieci, w których bezdomni szukają wartościowych rzeczy dla siebie (zdjęcie 31). Jeden z nich pokazał dom z przeszłości oraz ruiny baraku, w których będzie mieszkał w najbliższej przyszłości, kontrastując w ten sposób przeszłość z przyszłością (zdjęcie 32). Jednakże przyszłość jest najczęściej związana z bezdomnością. 


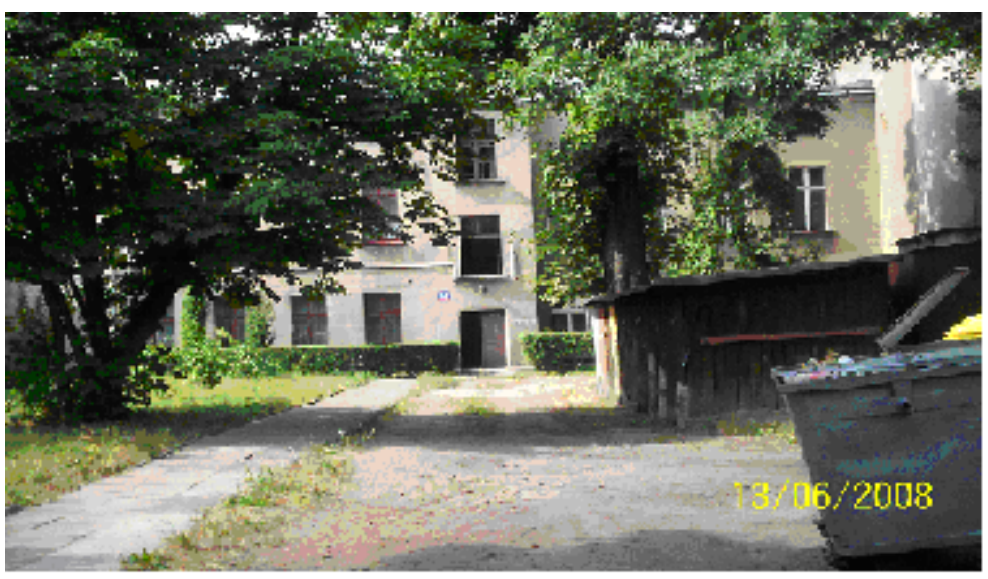

Fotografia 29. Miejsce gdzie bezdomny mieszkał poprzednio (perspektywa przeszłościowa; fotografia z własnego projektu badawczego).

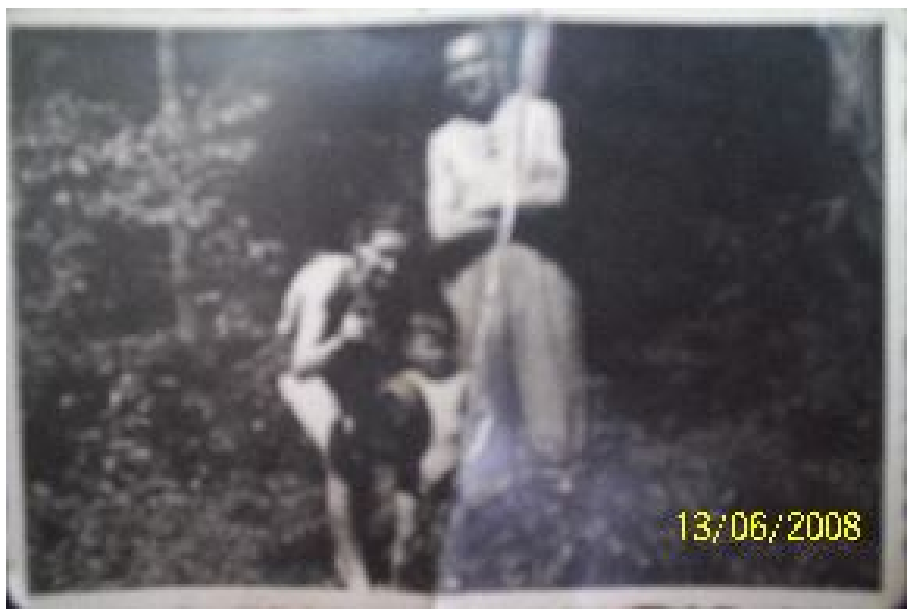

Fotografia 30. Fotografia fotografii z „poprzedniego życia” (perspektywa przeszłościowa; fotografia z własnego projektu badawczego).

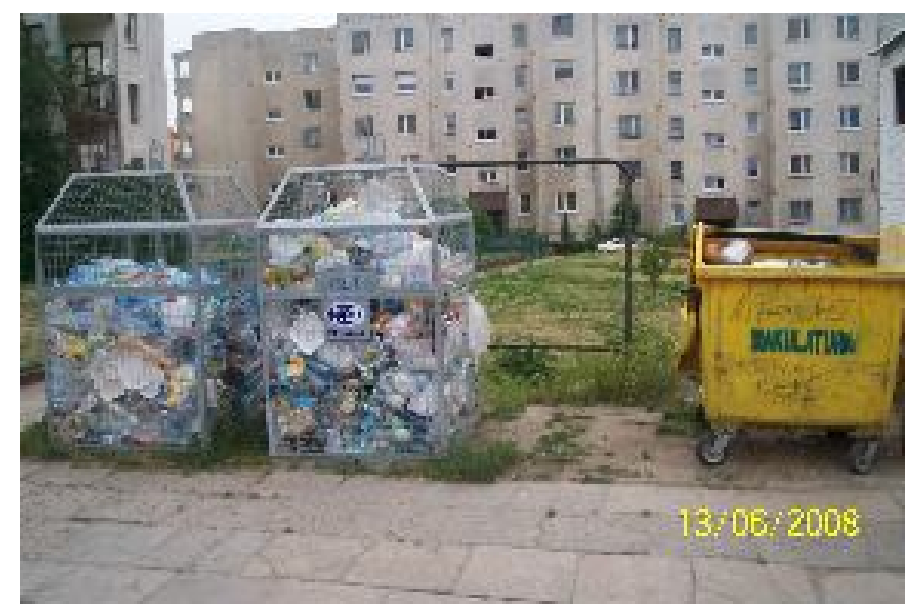

Fotografia 31. Rzeczywistość zamieszkiwania na ulicy. Perspektywa teraźniejszości. Praca na śmietnikach (fotografia z własnego projektu badawczego) 


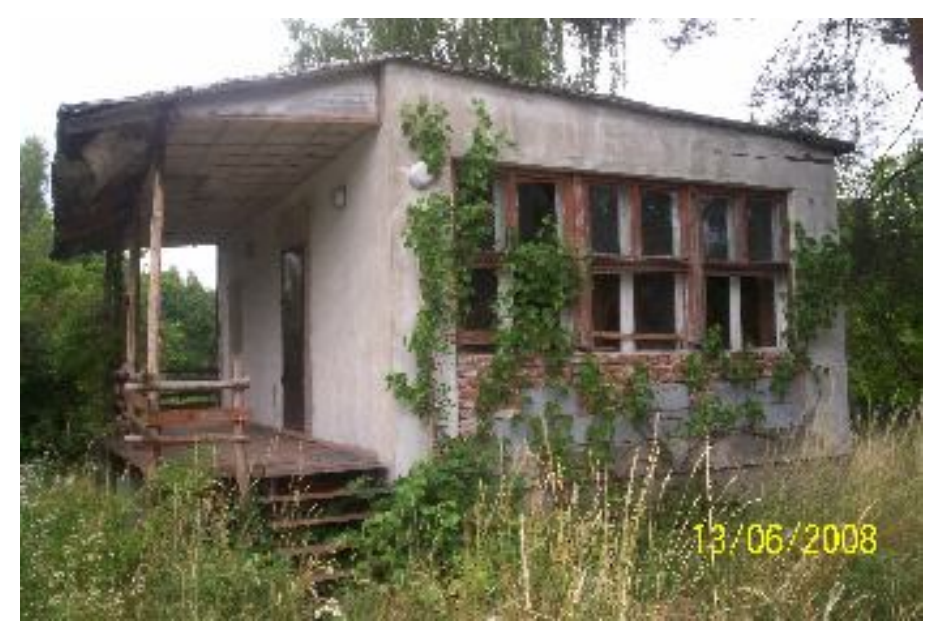

Fotografia 32. Przyszłe miejsce „zamieszkania” - perspektywa przyszłościowa (fotografia z własnego projektu badawczego).

Jak zostało wspomniane, bezdomni pokazują przede wszystkim miejsca i ikony z ich obecnego życia. Są oni zanurzeni w teraźniejszości. Niektórzy z nich pokazują miejsca, w których spędzają większość swojego czasu:

B. Gdybym miała zrobić zdjęcia i przedstawić Pana życie z przeszłości, teraźniejszości i z przyszłości, to co miałoby się znaleźć na takich zdjęciach?

R. Nie zastanawiałem się nigdy nad tym, to trudno powiedzieć. Ale tutaj jest takie miejsce, bo ja się pralnią zajmuję, to jest takie moje małe hobby, może nie tyle hobby, co znalazłem sobie miejsce tutaj, żeby się wyalienować od reszty, tam jestem sam, mam wszystko co potrzeba, łącznie $\mathrm{z}$ telewizorem i innymi rzeczami. Tam przebywam najdłużej jak tylko mogę. (bezdomny mężczyzna ze schroniska).

Wizualne obrazy są współtworzone razem z informatorami, widzimy z sekwencji wypowiedzi i ich komentarzy, że bezdomni mężczyźni nie mają doświadczenia z takimi pytaniami i problemami na temat kontrastowania wymiarów czasowych. Jednakże bezdomny ze schroniska odpowiedział i pokazał miejsce, które jest dla niego obecnie bardzo ważne (zdjęcie 33).

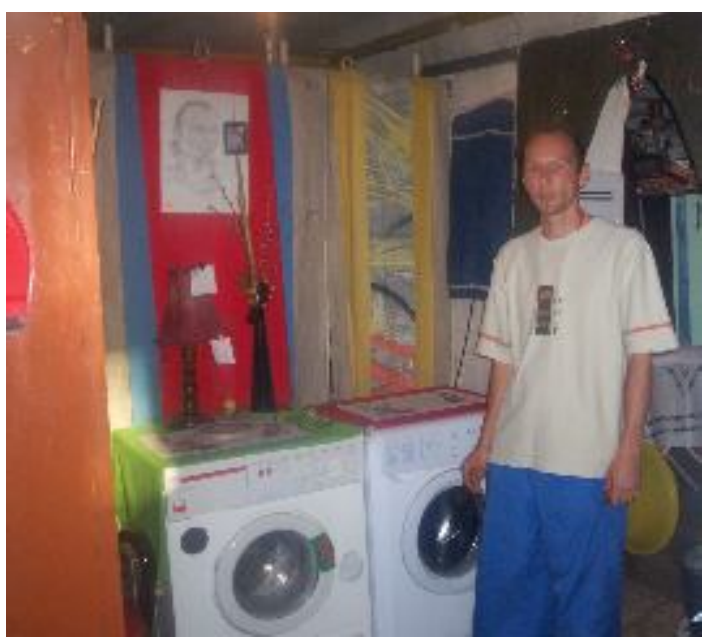

Fotografia 33. Najbardziej ulubione miejsce w czasie teraźniejszym, pralnia. Brak odniesień do przeszłości i przyszłości. 
Aktualne (teraźniejszość) warunki życia są również kojarzone z pewnymi czynnościami, które są wykonywane w schronisku. W jednym z łódzkich schronisk jest klub fotograficzny i bezdomni mężczyźni wskazują na kolekcję zdjęć zaprezentowanych na półce (zdjęcie 34), niedaleko miejsca, gdzie aktualnie mieszka (zdjęcie 36).

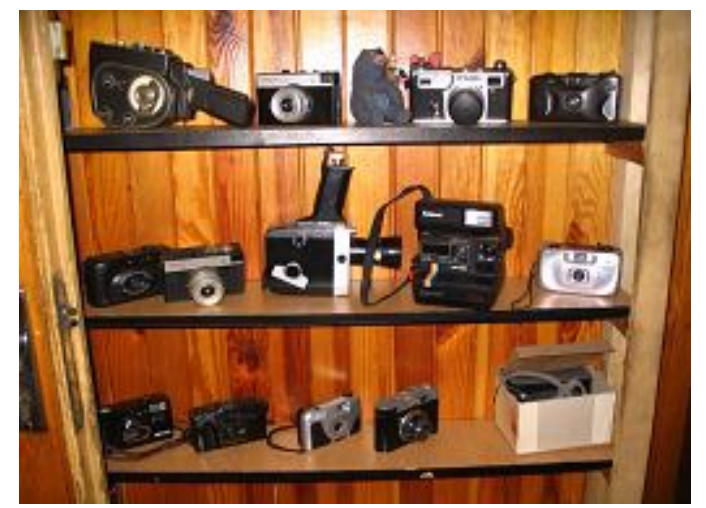

Fotografia 34. Kolekcja aparatów fotograficznych i kamer; klub fotograficzny w schronisku; czas teraźniejszy; fotografowanie (fotografia z własnego projektu badawczego).

Bezdomni mogą także pokazać przedmioty lub elementy otoczenia, z których są dumni, na przykład sadzawka przed schroniskiem, która została przez bezdomnego skonstruowana. To jest duma osadzona w teraźniejszości, chociaż sadzawka została stworzona wiele lat temu (zdjęcie 35). Bezdomny mężczyzna zrobił pewne niejasne uwagi dotyczące przyszłości, że pewna kobieta zamierza zabrać go do Włoch; jego uwagi wydały się być fantastyczne.

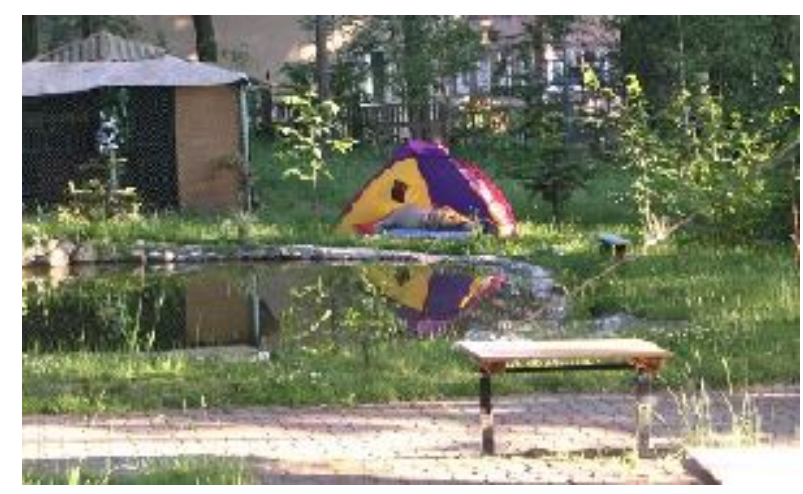

Fotografia 35. Kostka w chodnikach i staw przed schroniskiem skonstruowany przez bezdomnego. Duma w czasie teraźniejszym (podczas wykonywania fotografii badacz nieintencjonalnie uchwycił także namiot przed którym jeden z bezdomnych aktualnie spał; (perspektywa teraźniejszości; fotografia $z$ własnego projektu badawczego) 


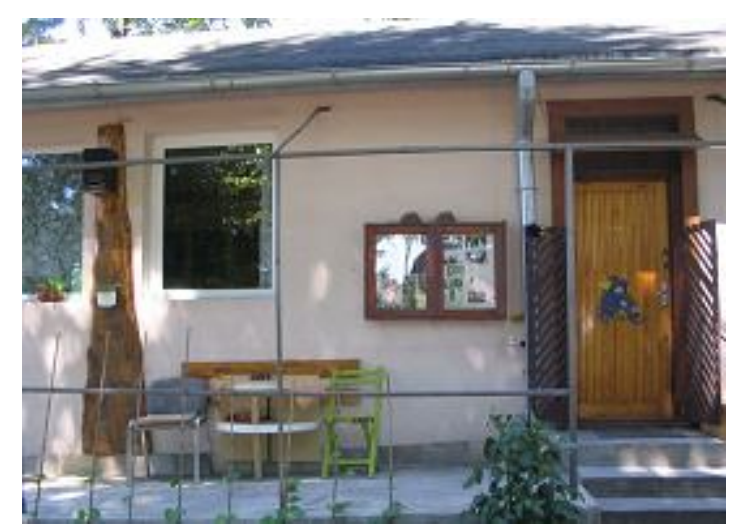

Fotografia 36. Miejsce lokalizacji klubu fotograficznego i miejsce zamieszkiwania bezdomnego mężczyzny, który jest dumny ze swoich dokonań odnośnie chodnika i stawu (perspektywa teraźniejszości; fotografia z własnego projektu badawczego).

\section{Konkluzje}

Analiza fotografii i kontekstów fotografowania, którą wykonaliśmy przypomina strategię badawczą wizualnej etnografii. Obrazy możemy znaleźć wszędzie (Pink 2007). Chcemy zaznaczyć, że wizualna etnografia jest metodą zbierania danych gdzie obrazy mają wzbogacić nasze obserwacje i dane o charakterze tekstowym. Natomiast metodologia teorii ugruntowanej jest zestawem procedur pomagającym analizować zebrane dane empiryczne. Etnografia czy obserwacja uczestnicząca i wywiady mają tylko pomóc badaczom być blisko uczestników i pomóc zrekonstruować badaczom konceptualnie doświadczenia uczestników (Charmaz 2009; Bryant, Charmaz 2007). Fotografie mogą być szczególnie użyteczne w metodologii teorii ugruntowanej inspirowanej interakcjonizmem symbolicznym, gdzie „bezpośrednia i bliska znajomość” (intimate familiarity) i definicje sytuacji uczestników są niezwykle istotne w rozumieniu i wyjaśnianiu ich życia (Strubing 2004, 2007; Clarke 2005). Wizualne dane i obrazy, które zostały użyte w naszych badaniach były niezwykle znaczące dla generowania kategorii mających uczulający charakter. Miały one duże znaczenie w procesie nauczania studentów teoretycznej wrażliwości (Glaser 1978), kiedy „wrażliwość wzrasta wraz z ekspozycją badacza wobec danych” (Corbin, Strauss 2007: 230). Wizualne reprezentacje dają nam jednocześnie naturalistyczny wgląd $w$ teren oraz pokazują jak dane są konstruowane i jednocześnie jak są tworzone kategorie teoretyczne?

Widzimy, że sekwencjonowanie fotografii jest bardzo użytecznym narzędziem dydaktycznym w nauczaniu wrażliwości odnośnie rozumienia jakiegoś substantywnego obszaru oraz w generowaniu bardziej ogólnych kategorii. Porównywanie obrazów zmusza studentów do poszukiwania w fotografiach wspólnych i jednocześnie różnych elementów rzeczowych i w konsekwencji również formalnych. Studenci widzą też, że dane empiryczne są konstruowane, szczególnie gdy mamy do czynienia z kooperatywnym podejściem i badani wspólnie z badaczami je konstruują, jak na przykład miało to miejsce $z$ wykonywanymi według instrukcji bezdomnych fotografiami.

Badacz i analityk powinien kłaść również nacisk na szczegółową transkrypcję danych by zaobserwować wewnętrzne procesy zachodzące w wizualnym wymiarze danych sytuacji i otworzyć dany obraz na analizę konceptualną. Jeśli dany obraz nie pasuje do sekwencji i generowanego wzoru interpretacji, powinien on zostać 
dokładnie przeanalizowany przez badacza i stać się pierwszym obrazem w nowo tworzonej sekwencji (zob. fotografia $37 \mathrm{w}$ Załączniku). Sekwencja powinna być utworzona $\mathrm{w}$ ten sposób by nasycić i zdefiniować nową kategorię i nowy wzór interpretacji, który został wygenerowany przez znalezione dystynkcje i własności w danej fotografii. Teoretyczne pobieranie próbek wytwarza nam sekwencje, wtedy gdy nowy obraz zostaje wygenerowany w terenie na podstawie analizy, pisania not teoretycznych i stawiania pytań.

Nasycanie kategorii może być podparte użyciem fotografii przedmiotów i miejsc. Fizyczne przedmioty i przestrzeń są ściśle związane z działaniami i wspólnie z aktorami wytwarzają działania, którzy interpretując w określony sposób świat podtrzymują lub doprowadzają do zaniechania działań. Czasami widzimy więcej na obrazach niż moglibyśmy uzyskać z werbalnych wypowiedzi badanych. Jest to bardzo istotny wniosek, do którego studenci dochodzą w trakcie badań terenowych. Bezdomni nie mogą, a często i nie chcą przedstawić w pełni swoich warunków życia w sposób werbalny. Wiele spraw jest oczywistych i nie w pełni uświadamianych i werbalizowanych. Ich otoczenie jest dla nich czymś oczywistym. Fotografie pokazują również często więcej niż zamierzał to fotograf, pokazują kontekst działań aktorów. Tło i detale sytuacji przedstawiają często ważne informacje o wielu aspektach życia codziennego bezdomnych (np. brak podziału na przestrzeń prywatną i publiczną). Wizualne reprezentacje miejsc ich życia mogą pomóc nam w nasyceniu kategorii „fizyczne warunki życia” z pełnym zestawem własności odnoszących się także do działań będących konsekwencją „fizycznych warunków ich życia”. Poznanie „fizycznych warunków życia” bezdomnych uczula także studentów w procesie dydaktycznym na konieczność ciągłego kontaktu z badanymi i z terenem badania.

Studenci powinni użyć metody ciągłego porównywania by porównywać typy badanych osób ukazanych na fotografiach. Kiedy porównujemy obrazy bezdomnych mieszkających w schroniskach z bezdomnymi wędrującymi i żyjącymi na ulicy widzimy, że zdjęcia ze schronisk mają charakter grupowy. Bezdomni z ulic są bardziej "niezależni” i żyją generalnie samotnie lub w parach, tylko czasami w większych grupach. Nie pozwalają się raczej fotografować. Bardzo efektywne okazało także porównywanie obrazów dla generowania własności kategorii „perspektyw czasowych”. Bezdomni żyjąc głównie z chwili na chwilę ukazywali wizualnie perspektywę skoncentrowaną na teraźniejszości. Ten wniosek potwierdziły także dane z wywiadów przeprowadzonych przez studentów. Metoda ciągłego porównywania wydaje się być najważniejszą metodą wizualnej teorii ugruntowanej, a także instrumentem nauczania analizy danych i wypracowywania teoretycznych kategorii i hipotez. Jednak procedura ta musi być używana razem z innymi, takimi jak teoretyczne pobieranie próbek, nasycanie i sekwencjonowanie danych wizualnych. Studenci poznają zatem całościowy charakter użytej metodologii, uświadamiając sobie, że użycie jednej lub kilku procedur nie upoważnia ich do nadużywania nazwy określonej metodologii. By można było powiedzieć, że metodologia teorii ugruntowanej została użyta w badaniu trzeba użyć wszystkie niezbędne procedury w określonym badaniu i analizach danych.

Pojawia się w związku z tym pytanie: czy powinniśmy wypracować teorię kiedy nauczamy metodologii teorii ugruntowanej? Sądzę, że możemy osiągnąć pewien poziom teoretyczny kiedy analizujemy dane ze studentami by stawiać pytania teoretyczne oraz na tej podstawie dokonywać teoretycznego pobierania próbek. W trakcie nauczania nie osiągniemy prawdopodobnie poziomu zintegrowanej teorii, ale powinniśmy osiągnąć pewną konsolidację kategorii (zob. Diagram 1) oraz pewne 
hipotezy, oczywiście powiązane ze sobą, powinny być także sformułowane. Nauczanie poprzez projekty powinno pokazać pewne rezultaty. Jeśli dane są analizowane to pojawią się także teoretyczne wnioski, a przede wszystkim, co jest z dydaktycznego punktu widzenia najważniejsze, pojawią się pytania teoretyczne i pewne wskazania do konstruowania nowych kategorii (zob. Fotografia 37), w tym kategorii o dużej mocy integrującej dane i konstruowane hipotezy.

\section{Bibliografia}

Anderson, Nels (1923/1965) The Hobo. The Sociology of the Homless Man. Chicago, London: Phoenix Books, The University of Chicago Press.

Banks, Marcus (2007) Using Visual Qualitative Data. LA, London, New Delhi, Singapore: Sage.

Blumer, Herbert (1969/2007) Interakcjonizm symboliczny. Kraków: Nomos.

Bryant, Anthony i Kathy Charmaz (2007) The Sage Handbook of Grounded Theory. Los Angeles, London, New Delhi, Singapore: Sage.

Borkowska, Iwona i Radosław Skrobacki (2008) "Fotoopowieści kobiet i mężczyzn co ich łączy, a co dzieli?" w Do zobaczenia. Socjologia wizualna w praktyce badawczej, pod redakcją J. Kaczmarek. Poznań: Wydawnictwo Naukowe UAM.

Charmaz Kathy (2009) Teoria Ugruntowana. Praktyczny przewodnik po analizie jakościowej. Warszawa: PWN.

Chenail, Ronald (2004) When Disney meets the research park: Metaphors and models for engineering an online learning community of tomorrow. Internet and Higher Education, 7(2), 107-121. Dostęp: 14.02.2009 http://www.nova.edu/ ron/Disney.pdf.

(2008) "YouTube as a qualitative research asset: Reviewing user generated videos as learning resources." The Weekly Qualitative Report 1(4), 18-24. Dostęp: 14.02.2009 http://www.nova.edu/ssss/QR/WQR/youtube.pdf.

Chenail, Ronald J., Spong, Jennifer L., Chenail, Jan, Liscio, Michele, McLean, Lenworth. G., Cox, Holly G., Shepherd, Brenda i Mowzoon, Nura C. (2006). "Creating and using learning objects in qualitative research education." The Qualitative Report 11(3): 450-473. Dostęp: 14.09.2009 http://www.nova.edu/ssss/QR/QR11-3/chenail.pdf

Chenail, Ronald. J., St. George, Sally, Wulff, Dan, Duffy, Maureen, Laughlin, Martha, Warner, Kate i Sahni, Tarmeen (2007). "Mentoring qualitative research authors globally: The Qualitative Report experience." The Qualitative Report, 12(1): 6781. Dostęp: 14.02.2009 http://www.nova.edu/ssss/QR/QR12-1/chenail.pdf

Clarke, Adele (2005) Situational Analysis: Grounded Theory after the Postmodern Turn. Thousand Oaks, Ca: Sage.

Corbin, Juliet i Anselm Strauss (2007) Basics of Qualitative Research. Techniques and Procedures for Developing Grounded Theory. 3rd Edition. London: Sage.

Drozdowski, Rafał (2008) "Autodefiniujące pamiątki." w Wyobraźnia społeczna. Horyzonty - źródła - dynamika. Uwarunkowania strategii dostosowawczych 
współczesnego społeczeństwa polskiego - studium socjologiczne, pod redakcją R. Drozdowski i M. Krajewski. Poznań: Wydawnictwo UAM.

Drozdowski, Rafał i Marek Krajewski, redaktorzy (2008) Wyobraźnia społeczna. Horyzonty - źródła - dynamika. Uwarunkowania strategii dostosowawczych współczesnego społeczeństwa polskiego - studium socjologiczne. Poznań: Wydawnictwo UAM.

Glaser, Barney (1965) "The Constant Comparative Method of Qualitative Analysis." Social Problems 12(4): 436 - 445.

. (1978) Theoretical Sensitivity. San Francisco: The Sociology Press.

Glaser, Barney i Anselm Strauss L. (1967) Discovery of Grounded Theory. Strategies for Qualitative Research. Chicago : Aldine.

Goode, David (2007) Playing With My Dog Katie. An Ethnomethodological Study of Dog- Human Interaction. West Lafayette, Indiana: Purdue University Press.

Hesse - Biber, Sharlene N. (2007) "Teaching Grounded Theory." W The Sage Handbook of Grounded Theory, pod redakcją A. Bryant i K. Charmaz. Los Angeles, London, New Delhi, Singapore: Sage.

Hurworth, Rosalind E. (2008) Teaching qualitative research: Cases and issues. Rotterdam: Sense Publishers.

lacocca, Lee i William Novak (1984) laccoca - An Autobiography. New York: The Bantam Dell Publishing Group.

Johnsen, Sarah i John May and Paul Cloke (2008) "Imag(in)ing 'homeless places': using auto - photography to re-examine the geographies of homelessness." Area 40(2): $194-207$.

Jahoda, Marie, Paul Lazarsfeld, Hans Zeisel (2007) Bezrobotni Marienthalu. Warszawa: Oficyna Naukowa.

Knoblauch, Hubert i Bernt Schnettler, Jurgen Raab, Hans Georg Soeffner (2006) Video Analysis: Methodology and Methods. Qualitative Audiovisual Data Analysis in Sociology. Frankfurt am Main: Peter Lang.

Kaczmarek, Jerzy, redaktor (2008) Do zobaczenia. Socjologia wizualna w praktyce badawczej. Poznań: Wydawnictwo Naukowe UAM.

Konecki, Krzysztof Tomasz (2000) Studia z metodologii badań jakościowych. Teoria ugruntowana. Warszawa: PWN.

----- (2008) "Dotyk i wymiana gestów jako element wytwarzania więzi emocjonalnej. Zastosowania socjologii wizualnej i metodologii teorii ugruntowanej w badaniu interakcji zwierząt i ludzi." Przegląd Socjologii Jakościowej IV(1). Dostęp grudzień 2008 http://www.qualitativesociologyreview.org/PL/Volume6/PSJ_4_1_Konecki.pdf.

Liberman, Kenneth (2004) Dialectical Practice In Tibetan Philosophical Culture. An Ethnomethodological Inquiry Into Formal Reasoning. Lanham, Boulder, New York, Toronto, Plymouth, UK: Rowman \& Littlelfield Publishers.

Mastenbroek, Willem (2000) "Organizational Behaviour As Emotion Management". S. 19-35 w Emotions in the workplace, pod redakcją Neal M. Ashkanasy, 
Charmine E.J Härtel i Wilfred J. Zerbe. Quorum Books, Westpoort, Connecticut/London.

Pink, Sarah (2007) Doing Visual Ethnography. London, Thousand Oaks, New Delhi: Sage.

Radley, Alan, Darin Hodgetts i Andrea Cullen (2005) "Vizualizing homlessness: a study in photography and estrangement." Journal of Community and Applied Social Psychology, 15: 273 - 295.

Schubert, Cornelius (2006) "Video Analysis of Practice and Practice of Video Analysis. Selecting field and focus in videography." W Video Analysis: Methodology and Methods. Qualitative Audiovisual Data Analysis in Sociology, pod redakcją H. Knoblauch, B. Schnettler, J. Raab, H. G. Soeffner. Frankfurt am Main: Peter Lang.

Silverman, David (2007) A Very Short, Fairly Interesting And Reasonably Cheap Book About Qualitative Research, LA, London, New Delhi, Singapore: Sage.

Strübing, Jörg (2004) Grounded Theory. Zur sozialtheoretischen und epistemologischen Fundierung des Verfahrens der empirisch begründeten Theoriebildung (Reihe: Qualitative Sozialforschung Bd. 15). Wiesbaden: VS Verlag für Sozialwissenschaften.

-----. (2007) Anselm Strauss. Konstanz: Uvk Verlags GmbH.

Suchar, Charles (1997) "Grounding visual research in shooting scripts." W Qualitative Sociology 20(1): 33-55.

\section{Załączniki}

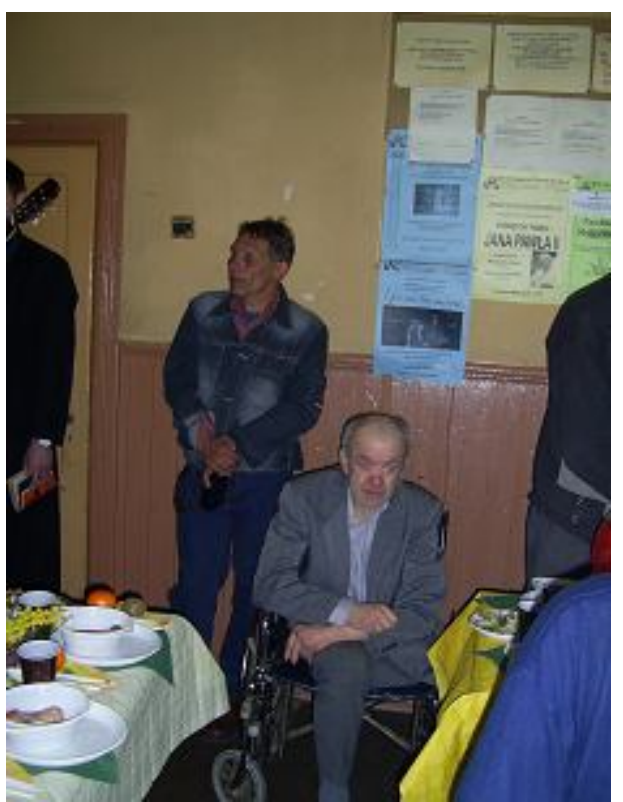

Fotografia 37. Nie została użyta w analizie, tylko zaprezentowana w pierwszej sekwencji na początku badań i analiz; może ona otworzyć nową sekwencję i pozwolić skonceptualizować kategorię „bezdomni żyjący z kalectwem”; fotografia nie pasowała nam do kategorii „kontrastowania”, chociaż widzimy tutaj podwójne oddzielenie przy stole: oddzielenie od tzw. normalnego „społeczeństwa” i jednocześnie od innych bezdomnych osób, bowiem bezdomny siedzi na samym rogu stołu. 


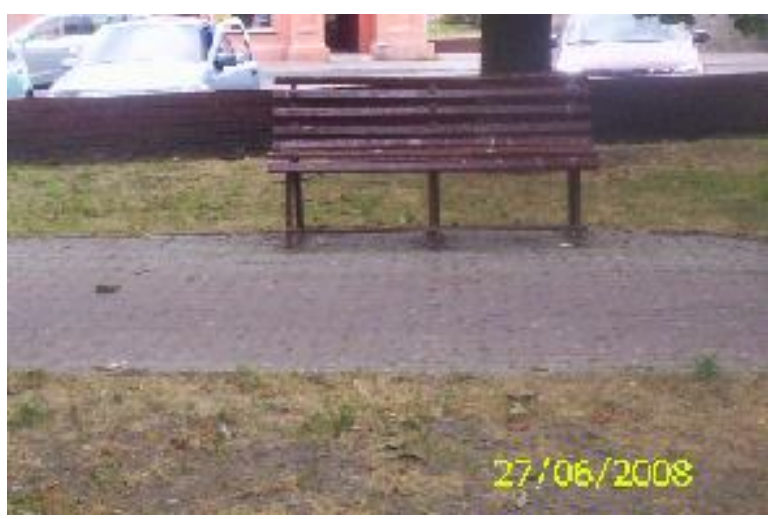

Fotografia 38. Ławka w parku, w którym najczęściej przebywają bezdomni. Wskazał ją bezdomny jako miejsce, gdzie najczęściej przesiaduje w ciągu dnia. Jest to dla niego miejsce, z którego obserwuje przechodniów.

\section{Cytowanie}

Konecki, Krzysztof Tomasz (2010) "Wizualna Teoria Ugruntowana. Nauczanie teorii ugruntowanej przy pomocy obrazów i analizy wizualnej". Przegląd Sockologii Jakościowej Tom VI, numer 2, Pobrany Miesiąc, Rok (http://www.qualitativesociologyreview.org/PL/archive_pl.php). 